\title{
Female ownership, firm age and firm growth: a study of South Asian firms
}

Article

Accepted Version

Belitski, M. and Desai, S. (2021) Female ownership, firm age and firm growth: a study of South Asian firms. Asia Pacific Journal of Management, 38 (3). pp. 825-855. ISSN 1572-9958 doi: https://doi.org/10.1007/s10490-019-09689-7 Available at https://centaur.reading.ac.uk/90524/

It is advisable to refer to the publisher's version if you intend to cite from the work. See Guidance on citing.

To link to this article DOI: http://dx.doi.org/10.1007/s10490-019-09689-7

Publisher: Springer

All outputs in CentAUR are protected by Intellectual Property Rights law, including copyright law. Copyright and IPR is retained by the creators or other copyright holders. Terms and conditions for use of this material are defined in the End User Agreement.

\section{www.reading.ac.uk/centaur}

\section{CentAUR}

Central Archive at the University of Reading

Reading's research outputs online 


\title{
Female ownership, firm age and firm growth: Evidence from South Asian firms
}

\begin{abstract}
This study investigates the role of female ownership, and its moderating role in shaping the effect of firm age and access to finance on firm growth. We use a sample of 7,203 firms in Bangladesh, India and Pakistan and a mixed effects model, where both firm and regional characteristics are included. First, we test how women's ownership affects two measures of firm growth (employment growth and Birch Index). Second, we investigate how women's ownership influences the relationship between firm age and access to finance for firm growth. Our results indicate that gender is an important determinant of firm growth, but this is closely tied to firm age, access to finance, and varies with region and country. We conduct a robustness check using firm productivity instead of growth and we find largely opposite results for productivity compared to employment growth ownership. We also identify questions that emerge from our findings for managers and policy makers interested in women-owned firms.
\end{abstract}

Keywords: women, owner, South Asia, firm age, employment growth, productivity JEL: L26 M13 R10 O17 


\section{INTRODUCTION}

...its potential is undermined by inequalities, including gender inequalities across all dimensions of economic and social life... Such impediments prevent South Asia from achieving truly equitable, inclusive and sustainable development (UN-ESCAP, 2015).

Policymakers around the world point to the promise of female economic participation, particularly through business ownership (UN-ESCAP, 2013), as a means to achieve economic growth and reduce poverty and inequality (see Cuberes and Teigner, 2016; Cuberes et al., 2016). However, harnessing the promise of female business owners is uneven in different contexts: for example, women own less than 10 percent of formal small and medium enterprises in South Asia, compared with 38 to 47 percent in East and Central Asia and Eastern Europe (World Bank Group, 2014).

Gender can have direct and indirect effects on firm activities and performance (Estrin and Mickiewicz, 2011), such as exports, profits, innovation and various types of firm growth. The role of owner gender in firm growth has been addressed from a very general standpoint (Ahl, 2006; De Bruin et al., 2007). Most prior studies focus on factors for firm growth like education and work background of women owners, motivation, skills, networking, and corporate entrepreneurship. Despite study of firm size and age on firm growth (see Haltiwanger et al., 2013; Birch, 1987), and the role of capital (see Coleman, 2007; Marlow and Patton, 2005), there has been limited investigation of the interplay between female ownership, firm age and access to finance on firm performance (see Denzo and Ross, 2012; Coleman, 2007; Marlow and Patton, 2005).

This knowledge gap is particularly wide for developing countries, as most research on components of these relationships is based on evidence from developed countries, such as the United States, Spain or Denmark (Shrader et al., 1997; Kochan et al., 2003; Alonso-Almeida, 
2013; Brush et al. 2017). Due to differences in institutional constraints and even physical barriers (e.g. personal safety) for women, findings from the extant research on developed countries are difficult to translate and apply to developing contexts like South Asia, where women face pervasive barriers (UN-ESCAP, 2015; Solotaroff and Pande, 2014) that can be deeply embedded (see Gaur et al. 2014). In addition, many developing countries are introducing reforms related to the legal gender gap (World Bank, 2019), so the environment in which women business owners operate can be changing rapidly.

In order to address this knowledge gap, we investigate women ownership in firm growth across the lifecycle of a firm, as well as the interplay of access to finance. Our cross-sectional data includes 7,203 firms in Bangladesh, India and Pakistan over two periods during 2007-2014. First, we explore growth in women-owned firm, focusing on employment-based measures of growth. Second, we apply a mixed effects multilevel model to test for the influence of a women owner in firm growth, as well as the role of firm age and access to capital. We also conduct a robustness check using productivity growth.

Our multilevel model allows us to account for a firm's embeddedness in two geographical contexts tied to regional and country location in Bangladesh, India, and Pakistan. We use two samples for India to account for potential dynamics tied to three states. We consider some key regulatory, normative and cognitive factors in South Asia in our multi-level model.

Our results indicate a highly nuanced influence of women ownership, which can vary based on firm characteristics as well as the type of firm growth measure being studied. We find that a woman owner has a positive influence on employment growth across the three countries in our study, as well as on a firm's overall job creation power (Birch Index) in Bangladesh and Pakistan, and in three key Indian states. We find mixed results for women-owned firms along the 
firm lifecycle and under capital constraints, compared to men-owned firms. Employment growth is slower in women- than men-owned firms along the firm lifecycle compared to the startup period for all except Bangladeshi firms, where it continues to be higher through 3-7 years. The Birch Index in women owned firms is smaller for those in Pakistan and in one India sample, but we do not find significant differences in our overall Indian sample. We also find that the Birch Index is larger for Bangladeshi firms for the period of 3-7 years compared to 0-3 years, after which the effect disappears.

We find mixed results for women-owned firms facing capital constraints, with a negative effect on employment growth in India, and a negative effect for job creation power (Birch index) in Indian and Pakistani firms. Finally, women-owned firms in India have rising labor productivity along the firm lifecycle, compared to 0-3 years. We also find largely different results for employment growth and our robustness check using productivity growth.

Our findings link firm age and feminist theories within the region and firm perspective, offering nuance to understanding growth outcomes of women-owned firms in some developing contexts. We find that heterogeneity in firm growth outcomes matters, and that a "one size fits all” approach does not advance understanding on womens' business ownership outcomes.

Our findings are useful to female owners in South Asia who may be considering when to invest in building financial and social networks in the lifecycle of the firms. Our findings could also be useful for investors and development interventions focused on women owned businesses. Our findings on when an increase in productivity may be seen, and in what region, raise questions for significant further investigation. Our work could also help policymakers who are considering if and how to support women in business. 
The rest of the paper is structured as follows. We provide context on our study next, and we develop our framework in Section 3. We explain our data, variables and method in Section 4, followed by results in Section 5. We discuss implications of the study and conclude in Section 6.

\section{THEORETICAL FRAMEWORK}

We contextualize our study by first assessing the state of current knowledge (see Gaur and Kumar, 2018) on female ownership in various institutional contexts. We identify key studies based on articles identified by keywords in leading international business, management and entrepreneurship journals, with a focus on 2006 onwards. The last two decades have seen growing interest in women in business (Rosa et al. 1996; Fairlie and Robb, 2009; Dezsö and Ross, 2012) but consensus on empirical evidence specifically on women and firm growth is elusive (Chirwa, 2008; Krishnan and Park, 2005; Du Rietz and Henrekson, 2000). In fact, a lack of consensus on approach, variable selection, and empirical technique on this question indicates the need for personal review related to availability of the data and prior research.

The existing literature points to mixed evidence on the direct effect of women ownership on firm growth. Some studies find that women-owned firms underperform men-owned firms (see Du Rietz and Henrekson, 2000; Fairlie and Robb, 2009) while others find that women-owned firms outperform men-owned firms (see Davis et al. 2010) or have no difference (Watson and Robinson, 2003).

While prior studies recognize that key factors, like resource allocation and network constraints, can affect women-owned firms, they do not typically consider their separate effects in empirical work (see De Bruin et al. 2007; Alfonso-Almeida, 2013). To better understand how women ownership can shape firm growth, we consider factors that enable women's involvement 
in decision making and firm ownership. It is also important to consider the lifecycle of firm, since a firm's needs and contributions at different stages of its lifecycle can vary (see Hyytinen and Maliranta, 2013), including need and access to growth-related resources. We elaborate on these factors as we develop our framework and empirical approach.

We are interested in the South Asian context in order to fill a gap in knowledge because the existing research on firm growth in general, and on women-owned firms specifically, has focused on advanced economies and given less attention to developing economies (Krasniqi and Desai, 2016; Dezsö and Ross, 2012) ${ }^{1}$. Much conceptual development on women in business originated in the study of advanced economies, rendering it contextually difficult to transfer assumptions to developing settings (see Desai et al., 2014). For example, some studies on firm growth have been conducted on the United Kingdom (Johnson and Storey, 1993) and United States (Fairlie and Robb, 2009; Brush et al. 2017). Yet while many developed economies mandate and enforce policies to increase gender representation, these types of reforms tend to be slow in developing economies (see Krasniqi and Desai, 2015).

\subsection{Women's ownership and firm growth}

Liberal feminist theory offers a starting point for our research. It posits that "men and women are essentially equal, but that women work at a disadvantage due to a lack of personnel, of financial resources or of access to power networks" (Alfonso-Almeida, 2013: 621). Liberal feminists argue that each woman has the right and ability to her own equal rights via her actions and choices (Fischer et al. 1993). Liberal feminism suggests that firm growth is a function of

\footnotetext{
${ }^{1}$ To some extent, the three countries in our sample offer a type of natural experiment, as all were part of British India: India and Pakistan were partitioned in 1947, followed by independence of Bangladesh (formerly East Pakistan) in 1971. Since and during the period 1947-1971, the countries diverged tremendously, not only in economic performance but also in social environment, governance and political conditions. Institutional transition has not been smooth or homogeneous across the three countries and their regions, cities and industries.
} 
organizational inputs, and gender differences are attributable to individual decision-making and managerial experience (see Orser et al., 2010).

This is meaningful because leadership in a firm can influence firm outcomes through decisions about resource allocation, firm goals, strategies and other internal and external firmorganizing activities (see Fairlie and Robb, 2009). Outcomes of women-owned firms can be affected by the mechanisms shaping their access to capital and labor resources. In some countries, legal and labor market regulations have reshaped the gender landscape of economic participation, paving the way for greater engagement of women in business. From a liberal feminist perspective, this implies that when women have the right and ability to participate equally (Fischer et al., 1993), there is no reason to expect different outcomes of economic activities undertaken by women compared with men.

Where legal requirements and labor markets reduce barriers or even promote women's participation in business, women should be able to take advantage of opportunities and access to resources similarly as men. In industries or occupations which are dominated by women, business activities by women may be accelerated, and networks embedded within those industries could favor women. Women can bring diversity of ideas, experiences, and market perspectives to the table, which can open new opportunities or business activities and processes. Thus, women can contribute to problem-solving (Van Knippenberg et al., 2004) through creativity (Kochan et al., 2003), thus boosting firm performance especially when women bring fresh eyes in industries which have previously been male-dominated.

This all suggests that we should expect a neutral (equal) impact of women owners on firm performance compared with men. However, the South Asian context complicates this 
expectation with three clusters of barriers that offer a reason to be more pessimistic: informal institutional barriers, formal institutional barriers, and physical barriers.

Socialization plays a central role in explaining business outcomes in the liberal feminism research (Alonso-Almeida, 2013). This parallels the importance of informal institutions related to social and cultural trends in the environment in which women business owners operate. Social capital, which includes resources within the connections networks of an owner, is largely construed as a positive force for entrepreneurs in studies on advanced economies (Lindvert et al., 2017). However, it cannot be ruled out that social capital could actually put firms at a disadvantage if it limits access to resources or inhibits action (see Wang et al., 2017). If masculine stereotypes dominate the context (see Schein 2007), social capital could more deeply embed stereotypes by concentrating access to networks and resources among men. Theorized diversity gains from women's problem solving and creativity (Van Knippenberg et al., 2004; Kochan et al., 2003) could be lost if the female presence complicates decision processes and raises their costs. For example, gender discrimination related to cultural expectations by others in the supply chain, such as buyers, suppliers and investors (Weiler and Bernasek, 2001), could make interactions more difficult.

Formal institutional barriers can exist in legal and regulatory systems, and can result from, e.g., educational systems, banking regulations, health systems, and inheritance laws. These can affect the participation and access of women to business opportunities. The 2018 Women, Business and the Law Report (World Bank, 2018) reveals that while progress has been made in the legal environment for women in the countries in our sample, there are still notable gaps. Some examples follow. Women can sign contracts and open banks accounts in the same way as men in all three countries. However, the law in all three countries does not prohibit 
discrimination by creditors based on sex or gender in access to credit. In India, women cannot work the same night hours as men. In Pakistan, women cannot legally register a business in the same way as a man. While men and women have equal ownership rights to immovable property in all three countries, daughters and female surviving spouses do not have equal rights to inherit assets in both Bangladesh and Pakistan. Even with equal inheritance laws in place, it requires that women are aware (e.g. access to information), willing (e.g. going against brothers or sons), and able to enforce the law (e.g. accessing courts with backlog and being able to finance the claim). If female heirs receive nothing or face difficulty accessing inheritance, this can have real economic consequences which could affect firm growth, e.g. through effects on direct financing of the business or activities that build a track record. Capital from inheritance can be used for education and training, subsidizing or offsetting household support needs to enable work outside the home, and startup costs like registering a business, acquiring production assets, etc.

A third set of barriers relates to physical safety, such as violence and safety, travel and transportation, which can put real constraints on mobility and access of women to regular business functions. Solotaroff and Pande (2014: xxvi) point out that women and girls in South Asia face a range of types of violence throughout their lives, presenting a serious problem that is difficult to quantify. Sexual exploitation of women in India, closely connected to domestic violence, can spill into the streets, creating fear and restricting mobility for women (see Bhattacharya, 2013). These dynamics can also affect ability to concentrate at school or at work (see Solotaroff and Pande, 2014) and in this manner, limit advancement in acquiring degrees or skill, which can limit future ability to engage in business activities. Women may have the right to travel outside the home in the same way as men (World Bank, 2018), but there still can be de facto risks associated with travel. Women owners who need to visit production facilities may 
face greater threats to personal security than men owners. They may not safely be able to travel to certain areas or even during certain parts of the day, limiting firm growth due to greater difficulty performing business operations.

Given the above combination of theory-driven optimism and context-driven pessimism, it is not possible to reasonably hypothesize on the direction of the effect of female ownership on firm performance in the South Asian context. However, given the central role of the business owner in driving firm outcomes (Robb and Fairlie, 2009), we expect that:

\section{H1: Female ownership is a significant factor driving firm growth in South Asia.}

\subsection{Female ownership, firm age, and firm growth in South Asia}

Firm age is a key factor shaping firm performance (Coad, 2018) and an important consideration in understanding the performance of women-owned businesses (Robb and Watson, 2012). A key challenge in unpacking the gender-firm growth relationship is that the needs of a firm can change over time.

Greiner (1972) laid out a model of firm growth comprising five phases, each the result of a "crisis". The ability of a firm's owner to manage each crisis is, to a large extent, dependent on ability to mobilize resources internal and external to the firm, to mitigate the crisis. The first phase for a new firm is growth through creativity, prompted by a crisis of leadership. After this, a firm grows through direction, prompted by a crisis of autonomy. Once the firm has survived this, it seeks growth through delegation, as a response to a crisis of control. The fourth phase of growth, as the firm is maturing, is growth through coordination, resulting from a crisis of red tape. Finally, the mature firm grows through collaboration, a response to undefined crisis.

Each crisis represents a marker which could deepen the advantage or disadvantage that a business owner faces, in building relationships, hiring, accessing capital, and managing other 
resources needed to grow the firm. Each next phase of the business may require different or greater resources to overcome, placing greater value on the track record of the owner.

We expect that the South Asian context places difficulty on female owners as their firms age and require greater resources. Traditional family and social structure in South Asia are also relevant as it could be that women are discouraged from working as they take on family responsibilities (see Still and Timms, 2000; Saari and Trihopoulou, 2003; Morris et al., 2006). A woman may close or leave the business, or it may be taken over by a spouse or a family member as it grows. Social capital, though usually considered to help business owners, could be a challenge in contexts where women face women limited social capital access outside the family or community (see Lindvert et al., 2017). For example, if a woman owner uses personal or family financing at the birth of her firm, and grows it to the point where it has export potential, the next step may require a significant capital infusion to scale production. This could mean she needs to seek external institutional channels for capital, which can open opportunity for gender discrimination and raise questions about collateralization and ownership of assets, which can be shaped by formal institutions favoring men.

Women may also face a disadvantage related to building relationships with bureaucrats, a relevant constraint for firms in South Asia, and may have to divert resources from growthoriented activities to do so. In fact, men and women owned firms in Bangladesh report that a senior manager spends on average 4.2 percent and 4.8 percent of time dealing with regulators, respectively. In India, the difference in even larger: men owned firms report a senior manager spends on average about 4.6 percent of time dealing with regulators, compared to almost double - 8.9 percent - spent in women owned firms (World Bank, 2014). 
It is difficult to reasonably predict how women-owned firms grow along the firm lifecycle. Based on a liberal feminist perspective, we would expect no real difference between women- and men-owned firms in contexts where women do not face the types of barriers described earlier. The three barriers described above call attention to the difficulties facing women business owners in South Asia. And, although South Asia had the fewest number of reforms related to the legal gender gap in the ten years leading to 2017, it was also the region with the highest percentage of reforming economies ${ }^{2}$ (World Bank, 2019).

Previous findings on the relationship between firm age and growth in the gender context have been mixed (Morris et al. 2006; Alonso-Almeida, 2013; Krishnan and Park, 2005). Some find that women-owned firms are likely to have fewer employees (Sarri and Trihopoulou 2005) as the firm ages, whereas other studies highlight that businesses are most at risk at the early stages (Robb and Watson, 2012) and that women-owned businesses tend to be younger than men-owned firms as they are more likely to exit the market over time (Rosa et al., 1996).

\subsection{Female ownership, access to capital, and firm growth in South Asia}

Using the lens of social feminist theory, women may have less access to financial resources than men (see Ahl, 2006; Orser et al., 2010) because the broader economic and social context favor masculine culture. For example, women-owned firms tend to start with less capital than men-owned firms (Marlow and Patton, 2005; Alsos et al., 2006; Fairlie and Robb, 2009), implying they have fewer resources to invest in growth-oriented activities. Gendered access to resources from the start will logically influence growth outcomes in the future.

\footnotetext{
${ }^{2}$ World Bank (2019) assesses reforms across and within regions for the period 2007-2017, and tracks a wide range of indicators related to the legal gender gap, including measures related to business and employment participation of women. Improvement by region could reflect both action taken as well the baseline of protections in a country.
} 
After the startup stage, women likely lack access to types of finance more often associated with growth, such as venture capital (see Morris et al., 2006) ${ }^{3}$. When men can more easily obtain financing than women (Coleman, 2007; Alonso-Almeida, 2013), they are at an advantage for future growth (see Alsos et al., 2006). Access to capital affects the ability of women-owned firms to hire labour, invest in growth-oriented activities and business development, and grow (Dezso and Ross, 2012), particularly in industries which require large immediate costs such as purchase of raw materials, and in companies which must be financially prepared to manage cash flows.

Access to capital is a significant barrier for entrepreneurs around the world, and for women entrepreneurs specifically (see Alonso-Almeida, 2013; Dezso and Ross, 2012). This bears out in the trend in South Asia: the firms in our sample show large differences in access to capital. For example, 56 out of 100 companies run by a woman secured external funding compared to 75 out of 100 companies run by a man (World Bank Enterprise Surveys). While we would not expect a difference between women and men-owned firms' growth outcomes where resources are equitably accessible, financial barriers in the South Asian context introduce some pessimism, so it is difficult to hypothesize on the direction of the relationship in this context.

\section{DATA AND METHOD}

We are able to leverage what is effectively a natural socioeconomic experiment of shared history and regional conditions, as we use three countries that were part of British India: India and Pakistan were partitioned in 1947, followed by the independence of Bangladesh (formerly

\footnotetext{
${ }^{3}$ It is also relevant to note more broadly that venture capital serves few entrepreneurs, even in countries where volume and size of the industry is large. For example, less than 1 percent of employer firms (firms with employees) in the United States reported using venture capital in the 2016 Census Bureau Annual Survey of Entrepreneurs.
} 
East Pakistan) in 1971. The countries diverged tremendously since partition and independence, not only in economic performance but also in social environment, governance and political conditions. Institutional transition has not been smooth or homogeneous across the three countries and their regions, cities and industries.

\subsection{Sample}

Our main data source is the Enterprise Surveys, a firm-level dataset produced by the World Bank (www.enterprisesurveys.com) in two waves on a rotating sample during 2007-2013. We also use country-level data from the World Development Indicators for control variables.

The Enterprise Survey compiled from face-to-face interviews with firm representatives and provides information on many trends relevant to a firm (e.g. leadership and ownership, human capital, performance, industry and business environment, infrastructure, technology, export orientation, and institutional characteristics), as well as region and country. The dataset provides exclusively cross-sectional information data (Chirwa, 2008; Rosa et al., 1996) which dates three years for a focal firm input. Two waves of the Enterprise Surveys were available for Bangladesh and Pakistan, and only one wave (2014) was available for India.

After cleaning the data for outliers, we used the maximum number of observations available for non-missing values for our model and replaced non-responses or all non-applicable with missing values. We obtain a final pooled sample of 7,203 observations (firms) for our main sample (using employment and Birch Index as dependent variables) and 6,508 firms for our robustness check sample (using firm productivity as the dependent variable). Out of 7,203 firms in our main sample, 5,547 firms were in India (including 910 firms in Maharashtra, Karnataka, and Delhi), 1,066 firms in Bangladesh, and 590 firms in Pakistan. 
Note that our final sample was built based on available data constrained by female ownership in 1,137 out of 7,203 firms. All firms in the Enterprise Survey could not be present in our sample due to data limitations and survey inconsistencies across countries, given the crosssectional nature of the data. The Enterprise Survey sampling was stratified and differential sampling was employed. This is why individual observations were weighted by the inverse of their probability of selection. Probability weights were applied by Enterprise Survey methodology.

Variables, sources and descriptive statistics for the full sample, women- and men-owned subsamples are listed in Table 1. Correlations for the full sample are reported in Table 2.

\section{-INSERT TABLES 1 AND 2 ABOUT HERE-}

\subsection{Dependent variable}

Finding a contextually suitable measure for firm growth is challenging, especially for developing countries which have high levels of informal economic activity, and across countries that may have varied accounting practices (see Krasniqi and Desai, 2016). Measures for firm growth can include monetary measures (sales, assets, profits) and employment growth. The problem with monetary measures is reliance on accurate reporting, and they do not take into account differences in relative prices, input proportions, and technologies. Some other measures do not reflect differences in firm activities by sector, for example between capital- and laborintensive sectors. We focus primarily on employment-based measures in our study because job creation is both closely linked to entrepreneurship in the literature and a key concern in many developing countries. 
Following Fisher et al. (1993) and Alonso-Almeida (2013), we use employment growth to measure firm growth, measured as logdifference in number employees over three-year period:

$$
\text { Growth }_{t}=\ln \left(S I Z E_{i, t}\right)-\ln \left(S I Z E_{i, t-3}\right)
$$

where SIZEi,t is firms's I employment (full -time) at time t.

Our second measure is the Birch Employee Growth Index (Birch, 1987). This reflects the job-creation performance of a firm by taking the product of absolute and relative job growth over three years for a firm. The Birch Index is useful because it enables comparison of firms of different sizes based on their job-creation power. We calculate employment growth (Birch, 1987) as follows:

$$
B I R C H_{i, t}=\left(S I Z E_{i, t}-S I Z E_{i, t-3}\right) *\left(S I Z E_{i, t} / S I Z E_{i, t-3}\right)
$$

In addition to our two employment-based measures of firm growth, we conduct a robustness check using firm productivity. We combine two measures of firm performance (Fisher et al., 1993) to calculate firm productivity as change in productivity over three years of sales per employee, reported on the Enterprise Survey, over three-year period p:

$$
\text { Productivity }_{i, t}=\ln \left(\frac{\text { sales }_{i, t}}{\operatorname{SIZE}_{i, t}}\right)-\ln \left(\frac{\text { sales }_{i, t-3}}{\operatorname{SIZE}_{i, t-3}}\right)
$$

where sales $_{i, t}$ is firm's sales at time t. We conduct this robustness check in light of significant heteroegeneity among firm outcomes (Audretsch et al., 2018).

\subsection{Explanatory and control variables}

Our key explanatory variable is woman owner, reflecting female ownership in a firm. It is measured as a binary variable from the Enterprise Survey: $1=$ a woman owns a share of the business (owner or co-owner) and $0=$ if otherwise. As with previous research (Brush, 1992), a firm is defined as being owned by a woman when the owner or a co-owner is a woman. 
We use proxies for firm age in age bands to account for the importance of the lifecycle of a firm (Dunne and Higher, 1995; Scott and Bruce, 1987). Previous research identifies at least five stages of the lifecycle of a firm (Greiner, 1972) which reflect functional and operational changes as a firm ages, such as activities related to inception, growth, and maturity of a firm. We assume that these changes are related to firm age. We use the number of years since operations started, as identified in the Enterprise Survey, to generate five age groups: 0-3 years (group one: startup), 3-7 years (group 2), 7-15 years (group 3), 15-30 years (group 4), and 30 years plus (group 5). Group one serves as the reference category. The average shares of women-owned firms at various ages in Pakistan, India and Bangladesh for the years 2009-2014 are shown in Figure A1 in Appendix. Exponential trends show a negative slope for Pakistan, indicating decreasing women ownership as firms age; positive slope for Bangladesh, indicating increasing women ownership as firms age; and neutral slope for India.

Our variable for access to finance comes from the Enterprise Survey and reflects the extent to which access to finance is considered an obstacle for business by firm representatives. It varies from zero (no obstacle) to one (moderate obstacle) and two (severe obstacle).

We also control for the possible influence of women through non-ownership roles in firms, as employees. We use two variables for women's labor participation in a firm, taken from the Enterprise Survey. First, we use women in non-production, measured as the percentage of females engaged in skilled (non-production) activities in a firm, which could also include women on the board (Davis et al., 2010; Dezso and Ross 2012), representing high-level female human capital. Second, we use women in production to capture female engagement at lower skill levels, measured as the percentage of women engaged in production activities in a firm. 
We also control for other firm characteristics relevant to firm growth. Given that our sample is South Asian firms, we accommodate the potential dynamics of informality using a question from the Enterprise Survey. We use formal birth to capture if the firm was formally registered when it began operations $(1=$ yes, $0=$ no). We do this because of the importance of registration status for firm growth, although it is still unclear whether firms register in order to pursue growth or if firms register once growth necessitates it (see Krasniqi and Desai, 2016). Including informality in our analysis is important as there could be a difference between when a firm opens and when it is formally registered (see Van Stel and Storey, 2004), as registration can happen after market entry in emerging and developing countries (see Aidis et al., 2012).

In order to capture the importance of the regulatory environment (Djankov et al., 2002), we include dealing with regulations. This is taken from the Enterprise Survey and measured as the share of senior management time spent dealing with government regulations. Firm exports can be an important determinant of firm growth and is measured as the percentage of a firm's sales from direct exports, taken from the Enterprise Survey. We measure digital readiness and the use of communications technologies in a firm, capturing if a firm reports in the Enterprise Survey that it communicates in the supply chain by using email and the web (internet). This is important for firm growth because technology could drive growth through greater ability to meet demand for production or lower employment because of redundancies. We identify firms which use foreign technology because access to technologies can improve productivity and competitiveness in local and regional markets (Belitski et al., 2016). This is measured using a dummy variable for technology transfer which identifies if a firm licenses foreign technology (1 $=$ yes, $0=$ no) taken from the Enterprise Survey. 
Although not a panel dataset, we also control for country unobserved characteristics like economic development, using GDP per capita in constant PPP for Bangladesh, India and Pakistan. This is taken from the World Development Indicators. In addition, we control for the regional fixed effect within each country using the mixed effect model approach.

Finally, we use industry and year dummies to control for industry and time-specific effects, to account for possible variation in firm growth due to sector differences and firm characteristics within those industries (Smith et al. 2006; Belitski and Desai, 2015). We use the following 14 industries: garments, food, metals and machinery, electronics, chemicals and pharmaceuticals, wood and furniture, non-metallic and plastic materials, auto and auto components, other manufacturing, retail and wholesale trade, hotels and restaurants, other services. The other category is construction, transportation, etc.

\subsection{Empirical strategy}

We adopt the input-output model of a Cobb-Douglas production function, extended to include the role of women ownership in firm growth (Ahl, 2006; Smith et al. 2006; Dezso and Ross, 2012). As firms are nested in regions, and regions are located in countries marked by an institutional context (Audretsch et al. 2018; Gaur et al. 2014), we use a two-level mixed model where the first level of analysis is a firm and the second level is a geographic region in a country. The regional level can have important implications for firm performance. Access to larger labor markets allows firms to more easily access human capital necessary for operations. Also, culture and informal institutions vary across regions within a country and may affect decision making of women (see Smith et al. 2006; Autio et al. 2014). Regional characteristics are thus explicitly embedded into explaining firm performance. We use regions identified in the World Bank Enterprise Survey (2014): Six in Bangladesh (Barisal, Chittagong, Dhaka, Khulna, Rajshahi, 
Sylhet), twenty two in India (Andhra Pradesh, Arunachal Pradesh, Assam, Bihar, Chhattisgarh, Delhi, Goa, Gujarat, Haryana, Himachal Pradesh, Jammu and Kashmir, Jharkhand, Karnataka, Kerala, Madhya Pradesh, Maharashtra, Orissa, Punjab, Rajasthan, Tamil Nadu, Uttar Pradesh, Uttaranchal), and eighteen in Pakistan (Balochistan, Faisalabad, Gujranwala, Hub, Hyderabad, Islamabad, Islamabad/Rawalpindi, Karachi, Khyber Pakhtunkhwa, Lahore, Peshawar, Punjab, Quetta, Sheikhupura, Sialkot, Sindh, Sukkur and Wazirabad).

We run our two-level (firm - region) analysis in five cycles: (1) all firms in the sample, (2) India-only firms, (3) India Global, including only firms in Maharashtra, Karnataka and Noida-New Delhi because these subnational units contain commercial cores of Bombay, Bangalore, and Noida-New Delhi, respectively, (4) Pakistan-only firms, (5) Bangladesh-only firms. Using the India Global sample in the analysis allows us to consider that region could influence firm growth areas with greater connectedness or more robust markets concentrated around core cities. This is informed by economic geography and regional economics research on the importance of region for firm growth, including regional institutions, agglomeration economies and labor markets, and industry clusters (Audretsch et al., 2018, Gaur et al. 2014). The regions in the analysis represent home state location as identified in the Enterprise Surveys. A nested mixed effect multilevel model allows us to use a hierarchical structure such that firms are nested into their respective regions ${ }^{4}$. Multi-level regression contains both fixed and random effects. Fixed effects are estimated in addition to being indirectly estimated by covariances of random intercepts and slopes (McCulloch et al., 2008; Rabe-Hesketh and

\footnotetext{
${ }^{4}$ There is the limitation of not able to estimate with three levels, by adding random effects equations at the firm level with nesting going to biggest (country) level. However, with three countries, a three level model has small added power. Our dependent variable is already captured at the firm level, nested within a region in one of the three countries.
} 
Skrondal, 2012). We control for unobserved heterogeneity across regions using the following two-level random-intercept model:

$$
\mathrm{E}_{\mathrm{it}}=\beta_{0}+\sum_{i=1}^{k} \beta_{\mathrm{i}} X_{\mathrm{it}}+\sum_{z=1}^{n} \beta_{\mathrm{iz}} X_{\mathrm{itz}}+a_{z}+\lambda_{t}+e_{\mathrm{it}}
$$

where $\mathrm{i}=1, \ldots, \mathrm{K} ; \mathrm{z}=1, \ldots . ., \mathrm{N} ; \mathrm{t}=1, \ldots, \mathrm{T} ; \mathrm{E}_{\mathrm{it}}$ is firm growth $\mathrm{i}$ at time $\mathrm{t}$ nested in region $\mathrm{z}$ categorized by difference in employment, Birch Index and difference in productivity. $\beta_{i}$ is the corresponding coefficient of a vector Xit at a firm level with our variables of interest and control variables $\beta_{i z}$ is the corresponding coefficient of a vector Xitz at a regional -level. $\mathrm{X}_{\mathrm{itz}}$ is a $1 \times q i$ vector of $q$ regressors in a region $\mathrm{z}$ related to regional characteristics. $\mathrm{X}_{\mathrm{it}}$ is a $1 \times q i$ vector of $q i$ regressors in a firm i specific controlling for regional effects of firm growth. $\lambda_{t}$ is a time control. The random intercept is measured at region $a_{z}$ level and captures unobserved heterogeneity in the regional context, e.g. culture, traditions, industry specialization, degree of openness in relation to our dependent variable (Acs et al. 2014). The random intercept is assumed independent and normally distributed with zero mean and constant variance. Following Goldstein (2005), the error terms are assumed to be independent with $E($ eit $)=0$. and can therefore be directly estimated.

We follow Rabe-Hesketh and Skrondal (2012) as there is no statistical justification for imposing any particular covariance structure between random effects at the onset of our analysis. We first explore a model with an unstructured random effects covariance matrix, which allows for distinct variances and covariances between all random effects covariates at the same level. We also perform robustness check at the start of our analysis by fitting mixed effects models with an exchangeable covariance structure at the second level, but the results of predicted margins and significance of coefficients do not change (both for the full sample and countryspecific samples) when various assumptions on covariance structure are imposed. 
By using a mixed effect multilevel model, the influence of each level can be controlled for and measured, which is useful when dealing with possible endogeneity bias and potential spatial autocorrelation (Goldstein, 2005).

\section{RESULTS}

We use multilevel (two level) mixed effects model with a random intercept to examine how firm location and firm characteristics, including women ownership, firm age, and access to finance affect firm growth in a sample of 7,203 firms across 14 sectors in Bangladesh, Pakistan and India (2007-2014). We consider that both firm and external factors, such as regional and country characteristics (Belitski and Desai, 2015) can affect firm growth.

We calculate the baseline (random intercept only) model (Specification 1, Tables 3-4) to obtain the interclass correlation coefficients (ICCs) or between firm regional variation (RabeHesketh and Skrondal, 2012). The intercept is statistically significant at the $1 \%$ level and ICCs are between 0.08 and 0.04 (Table 4), suggesting sufficient evidence to pursue multi-level modeling (McCulloch et al., 2008) and that the regional context has certain explanatory power of firm performance (Acs et al. 2014).

Next, we estimate random intercept and fixed slope models with regressors at both the region and firm levels. Results in Table 3 refer to employment growth and results in Table 4 refer to the Birch Index. The results in Tables 3 and 4 are reported as follows: full sample of 7,203 firms (Specifications 2-3), India-only firms (Specifications 4-5), India Global firms (Specifications 6-7), Pakistan-only firms (Specifications 8-9) and Bangladesh-only firms (Specifications 10-11). We estimate the baseline model, as well as the baseline model modified to include an interaction term capturing women ownership, firm age and access to finance. 


\section{-INSERT TABLES 3 AND 4 ABOUT HERE-}

Tables 3 and 4 show the estimated variance components. An LR test comparing the model with one-level ordinary linear regression is provided and is highly significant for all samples except Bangladesh in Table 4, advocating for multilevel modelling but a model without regional effects for Bangladeshi firms. This does not mean that two level modeling is not appropriate for Bangladesh, rather than higher homogeneity across Bangladeshi regions.

The intra-class correlation coefficient (ICC) measures the degree of correlation among observations within a region, and is a useful tool to evaluate how much of the total variance in firm growth that can be assigned to regional factors (Gaur et al. 2014; Acs et al. 2014). The ICC coefficient ranges from 0 to 1 , where a value 0 , indicates that the regional characteristics have no effect on dependent variable and 1 indicate that all units in the region are relevant (Goldstein 2005; Nilsson et al. 2014). As shown in Tables 3 and 4, the estimated ICC varies between 0.02 and $0.13(2-13 \%)$ for the full sample, 0.02 and $0.08(2-8 \%)$ for the India sample, and 0.02 and $0.07(2-7 \%)$ for the Indian Global sample. For Pakistan, the ICC is between 0.02 and 0.08 (28\%). For Bangladesh, the ICC varies between 0.02 and $0.03(2-3 \%)$. The role of regional institutional characteristics is stronger in India than in Pakistan and Bangladesh which is likely due to greater differences in institutional and cultural context between regions in Pakistan and India, than Bangladesh.

We find some interesting overall trends in firm growth for the region. Firms aged 7 years or more are likely to create fewer jobs than firms below 7 years of age, particularly in India 
(Tables 3 and 4). However, once we account for a proportional contribution of firm growth using the Birch Index, this difference in job creation disappears (Table 4).

Findings for the control variables are largely consistent for firm growth measured using employment (Table 3) and Birch Index (Table 4). We found a direct positive association between high skilled women (women in non-production) and firm growth for all firms, except Pakistani firms and India Global cities firms, where it is not significant. We find that firms which were formally registered at the time of birth employ fewer people (Table 3), as do firms which license foreign technologies (Table 3, 4). We find that firms using communication technologies (email and website) within their supply chains have greater employment growth in the full sample, as well as sample of Indian firms and Bangladesh firms (Table 3, 4). Use of email and web in Pakistani and India Global cities does not provide an additional competitive advantage. We also find that time dealing with regulations is positively associated with firm size (Tables 3 and 4).

We now turn to our hypothesis, H1, which predicted that women ownership in a firm would be a significant factor for firm growth, but we were not able to predict a negative or position direction of the relationship. We find a weak positive effect for Bangladeshi firms $(\beta=6.02 ; p<0.10)$. We do not find significant positive effects for the Indian and Pakistan samples. The effect turns positive when we control for firm lifecycle and capital constraint factors (Table 3) for the full sample (37.89; $p<0.01)$, Indian firms $(\beta=33.47 ; p<0.01)$, Indian Global firms $(\beta=139.2 ; \mathrm{p}<0.01)$, Pakistan $(89.23 ; \mathrm{p}<0.01)$, and Bangladeshi firms $(\beta=1.58 ; \mathrm{p}<0.10)$. When using the Birch Index as the measure for firm growth (Table 4), we find a direct and significant effect for the full sample $(\beta=6.79 ; \mathrm{p}<0.01)$ and Bangladeshi firms $(\beta=28.69 ; \mathrm{p}<0.01)$. When controlling for firm age and capital constraints, firm age becomes positive and significant: $(\beta=22.44 ; p<0.10)$, India Global firms $(\beta=105.00 ; p<0.01)$, Pakistani firms $(\beta=333.9 ; p<0.01)$ 
and Bangladeshi firms $(\beta=23.54 ; \mathrm{p}<0.01)$. Interestingly, we find that in India, women ownership positively influences the Birch Index only in the India Global sample.

We find mixed evidence on the role of firm age. Along the lifecycle since startup, employment growth in women-owned firms is slower than men-owned firms, for all except Bangladeshi firms. For Bangladeshi firms, employment growth continues to be higher in womenowned firms through the period of 3-7 years (Spec. 11: $\beta=37.96, p<0.01$ ), after which the effect disappears (see Table 3). Along the lifecycle, being a women-owned firm is negatively associated with Birch Index (Table 4) for firms in the India Global sample and Pakistan sample. We do not find significant differences in the effect of firm age on Birch Index between women and men-owned firms in the overall Indian sample. Interestingly, female ownership is associated with higher Birch Index for Bangladeshi firms for the period of 3-7 years compared to 0-3 years, after which the effect disappears (Spec. 11: $\beta=83.38, p<0.05$ ).

We find mixed evidence on women-owned firm growth under constrained capital access. We find that women-owned firms in India experiencing severe financial constraints are likely to have lower employment growth (spec. 4-5: $\beta=-4.84, \mathrm{p}<0.10$ ) (Table 3). This is similar for Indian $(\beta=-4.95 ; \mathrm{p}<0.10)$ and Pakistani firms $(\beta=-70.60 ; \mathrm{p}<0.05)($ Table 4$)$ when the Birch Index is the dependent variable. In other words, women-owned firms that report access to finance as a severe barrier are less likely to hire more employees in India and Pakistan. Results are not statistically significant for Bangladeshi firms, meaning that women- and men-owned firms are likely to experience the same growth regardless of their relative difficulty in accessing capital.

\subsection{Robustness check}

We performed three types of robustness check in this study. First, we experimented with fitting mixed-effects models using exchangeable covariance structure and unstructured 
covariance structure for model estimation at the second level. The results of estimation with predictive margins, significance of coefficients and standard errors has not proved to be different for the full sample or for the country-only samples. For all estimations, we assume independent covariance structure between the random effects; that is, all covariances are assumed to be zero.

Second, the ICC is low for Pakistan and Bangladesh, and some region-specific effects do not change over time within the same firm location. A mixed effect model allows controls for region specific effects, but we also address this issue by exploiting fixed effects estimation as a robustness check (Wooldridge, 2002). We include country and regional dummies in the model controlling for country and regional -fixed effects when clustering standard errors. Results of the fixed effect model confirm our findings using mixed methods, both by calculating coefficients and statistics and by plotting predictive margins with $95 \%$ confidence intervals ${ }^{5}$. The major difference in two estimations is the significance of the coefficients is lower in mixed effect model but stronger in fixed effects model.

We conduct a robustness check using a proxy for firm growth - productivity. Findings are reported in Table A1 in the Appendix. Noteworthy findings from the robustness check are as follows. Interestingly, the results for our robustness check are different from our main results on firm growth (Tables 3 and 4). We found partial support for $\mathrm{H} 1$, which predicted female ownership would be a significant factor driving firm growth. In contrast to some of the positive results using employment-based measures of firm growth, we find that women-owned firms in Pakistan have lower labor productivity $(\beta=-1.33 ; \mathrm{p}<0.01)$. When controlling for capital barriers and firm age, we find lower productivity among women-owned firms in the India $(\beta=-0.38$; $\mathrm{p}<0.05)$ and Pakistan $(\beta=-2.85 ; \mathrm{p}<0.10)$ sample. Results for Bangladeshi firms are not

\footnotetext{
${ }^{5}$ Results are available from the authors upon request.
} 
statistically significant. Although our main estimations show that firms which formally registered at birth and which license foreign technologies had fewer employees, we find they have higher productivity in the robustness check.

The robustness check results are mixed for women-owned firms and firm age, as womenowned firms are likely to increase productivity over the lifecycle compared to startup. This result is largely driven by Indian firms that exhibit higher productivity if they survive (0-3 years since establishment) but not Bangladeshi and Pakistani firms. When it comes to capital constraints, we find that access to capital is not associated with productivity except for Pakistani women-owned firms: Pakistani women-owned firms reporting severe capital constraints $(\beta=3.36, p<0.01)$ were more productive. Firm productivity is a difference in sales to employment ratio over time, which is inversely related to firm employment: an increase in the number of employees decreases the ratio. This explains differences in findings associated with the way productivity is calculated as a proxy for firm growth.

In addition, we experimented with a lagged dependent variable as a control variable, but it was not statistically significant. A potential problem of such estimation is endogeneity in the data; given the cross-sectional nature of our data with two points in time available for each firm, a dynamic mixed effect model has weak statistical significance and the lagged dependent variable was not statistically significant. The data does not allow us to control for more than one lagged dependent variable on the right hand side (Wooldridge, 2002).

\section{DISCUSSION AND CONCLUSION}

We conduct a novel study on women owners and firm growth in South Asia, using firm age and access to finance as a prism for our analysis (Still and Timms 2000; Marlow and Patton, 
2005; Smith et al. 2006). We use a sample of 7,203 firms in Bangladesh, India and Pakistan to investigate both direct and moderating effects. Our study extends previous research on the role of women owners in firm growth (Rosa et al. 1996; Fairlie and Robb, 2009; Dezsö and Ross, 2012) by building largely from liberal feminist theory to explain how women experience business ownership.

We find that women-owned firms tend to have higher employment growth and higher Birch Index growth except for Global India regions. However, our robustness check using productivity as the dependent variable shows a negative effect of women ownership on productivity in Pakistani and Indian firms. Firms which hire more employees may not actually be more productive, unless sales change is greater than employment change (reflecting how productivity is calculated). This could also be driven by industry-specific characteristics which drive employment needs of growing firms, and industries with greater reliance on automation may see contrasting trends in employment and productivity growth. A single measure of firm growth is unlikely to account for such nuances adequately (see Krasniqi and Desai, 2015) and our findings demonstrate that firm growth should be examined from multiple perspectives and using both employment and non-employment based measures. Except for Pakistani firms, severe constraints when accessing finance were not found to affect firm productivity. For Bangladeshi firms, there may be a link to widespread microcredit financing, ${ }^{6}$ with a type of "leveling" the field phenomenon that may be related to the finding on productivity, similar to results from developed economies (Watson and Robinson, 2003).

\footnotetext{
${ }^{6}$ The microfinance industry in Bangladesh came out of Mohamed Yunus' experiment with the traditionally unbanked, least creditworthy asset class - poor women. High repayment rates and the social gains assumed with microfinance led to rapid popularity of the industry, demonstrated by the proliferation of microfinance in Bangladesh, leading to massive and artificial injection of capital into the economy. It is not surprising that access to capital was not a significant negative factor for growth of women owned firms in Bangladesh.
} 
Our findings also highlight the importance of considering that women's ownership interplays with other factors - specifically, firm age and access to finance - to shape firm growth. Women-owned firms hire more people earlier in their lifecycle, with the number of employees decreasing with firm age. After controlling for the proportional contribution of firms of all sizes, this effect remains significant for Indian global regions and Pakistan, while we find no differences in job creation (Birch index) between women and men-owned firms overall and in firms outside Global Indian cities.

Our results show that both firm age and severe capital constraints can limit growth in women-owned firms in the South Asian context. Severe financing difficulties are greater barriers for firm growth in India and Pakistan, but not do not hinder firm growth in Bangladesh. Interestingly, our robustness check indicated that access to capital is not associated with firm productivity, except for women-owned firms in Pakistan where severe barriers to finance are associated with more productivity. This implies a type of filtering of only the most productive women-owned firms which have been able to aggressively overcome financing barriers.

Our findings may be useful to women business owners. For example, some regions may be more conducive for women-owned businesses in India. When women own or co-own businesses, being aware of the challenges particularly during the first 0-3 years can help them identify what areas of firm operations to concentrate efforts. A key finding of our study is that women access capital differently than men (see also Alfonso-Almeida, 2013), but we also find that productivity of women-owned firms improves with firm age. This draws attention to women owners to consider how and when to seek capital or other support to help manage productivity at very early stages. 
Policymakers can consider some implications from our findings. Women-owned firms in Pakistan and India experience higher employment growth during early years (0-3 years) compared to later stages, while those which survived after the entry period demonstrate higher productivity over time, and in particular in India. Policymakers might consider how the lifeycle of the firm is relevant in their interventions based on if employment growth or productivity is the target. Policymakers could also consider how firm age matters if are considering targeting capital constraints.

Our findings indicate there is value in considering the nuances of capital for Indian firms outside the India Global subsample. However, this is complicated to interpret because the subsample comprises states which contain key commercial cities. The broader areas outside the key cities should be investigated further to understand the immediate, within-state dynamics of firm growth, before prioritizing any appropriate policy.

Our study confirms a gender gap in growth outcomes of women-owned firms, but that it is important to consider heterogeneity across firm characteristics, such as age, and types of growth. Our findings suggest that variations across regions, firm age, and many other firm characteristics are relevant considerations for policymakers to think about if they are considering targeted interventions.

\subsection{Limitations and directions for future research}

It is important to note several limitations about our study. As with many studies using data on developing contexts, we are constrained by availability and limitations of the data. In this study, we use proxies which adequately capture our variables of interest but leave some questions unanswered. Our main dependent variable, firm growth, uses employment-based proxies, which we consider appropriate measure given our context. It is important for 
policymakers and women owners to consider that we use several explicit measures of firm growth, and findings apply as such. However, it is worth noting that employment may not always match other measures. For example, employment may fall due to automation but revenues of the firm may rise (see Krasniqi and Desai, 2016). As our robustness check indicates, employment and productivity can manifest opposing patterns. A direction for future research is to better understand the link between employment growth and productivity (Autor and Salomons, 2018).

We use a proxy for women's ownership which captures if any of the owners is a women. As with previous research (Brush, 1992), a firm is defined as being owned by a woman when the owner or a co-owner is a woman. A limitation of this indicator that it cannot identify, in the case of more than one owner, characteristics of the other owner/s. For example, this does not reveal if a woman owns jointly with a spouse, which could be a salient question in South Asia because of the prevalence of family business in the economy (Economist, 2015; Carney and Gedajlovic, 2002). Our findings should be taken as they relate to the variables used in our study; while it may be tempting to treat positive performance of women-owned firms as indicative of broader female empowerment, our findings do not provide supportive or contrary evidence on this link.

Our final sample was built based on data on firm ownership with 1,137 women-owned businesses out of 7,203 firms. The Enterprise Survey sampling was stratified and differential sampling was employed; this is why individual observations were weighted by the inverse of their probability of selection. Probability weights were applied by Enterprise Survey methodology. However the use of the stratified sample may still include selection bias due to data limitations and survey inconsistencies across countries, given the data's cross-sectional nature. 
In this regard, an important methodological limitation relates to longitudinal data on firm ownership and survival. Such data would enable researchers to observe whether women ownership changes over firm's lifecycle and how this change is associated with outcome indicators, such as job creation and productivity over time. For example, do women sell their firms earlier or later than men?

Our study points to several directions for future work. An important question is on how women's ownership is associated with a variety of measures of firm performance, including quality and quantity of job creation, product development, innovation, exports and so on. Noneconomic outcomes are of special interest and especially in the context of our sample, such as how female ownership of firms may be tied to broader economic empowerment of women. It would be fruitful to explore, for example, whether ownership in firms leads to stronger financial security or participation in household decision-making, not only of the women owners but also of employees. The question of non-economic outcomes is salient also because women owners have been found to attempt to balance profits with non-economic goals, including accomplishment, professional development and helping others people by creating jobs (Brush, 1992).

Another direction for future research is to conduct multi-level analysis on individual and firm level data, to examine how individual personality traits are associated with different types of firm growth outcomes among women. This would also further calls for multi-level analysis of the factors driving firm entry and performance (Audretsch et al., 2018). An important question beyond South Asia is on the role of region and local context in shaping firm outcomes. Our findings for regions dominated by key cities in India raise questions about why women-owned firms in these regions perform better. It would be fruitful to ask, for example, if women might 
leverage social capital better in agglomeration economies because they can access deeper and larger networks, or in smaller regions where they may be more deeply entrenched in networks. It is also worthwhile for future research to ask how specific inputs or institutional frameworks in regions shape firm growth. When it comes to access to capital, is it better for women to be in regions with greater density of financial services or smaller regions, if personal ties are stronger?

Relatedly, future research on the relationship between firm age and size (e.g. Halitwanger et al., 2013) could seriously consider how women owners matter. For example, are women owners more effective in small or large firms, and at what ages, and in what places?

Finally, further research specifically on the South Asian context is important because of disparities in economic, political and social life for women. The pace of institutional reforms, coupled with slow-changing norms and traditions, and their effect on women in business and related outcomes represents an important nexus for both future research and policy (see World Bank 2019, 2016; Cuberes and Teigner, 2016; Cuberes et al., 2016).

\section{References}

Acs, Z., Autio, E. and Szerb, L. (2014) National systems of entrepreneurship: measurement issues and policy implications, 43(3): 476-494.

Ahl, H. (2006). Why research on women entrepreneurs needs new directions. Entrepreneurship Theory and Practice, 595-621.

Aidis R., Estrin S and Mickiewicz T. (2012). Size matters: entrepreneurial entry and government. Small Business Economics 39, 119-139.

Alfonso-Almeida, M. (2013). Influence of gender and financing on tourist company growth. Journal of Business Research, 66, 621-631.

Alsos, G., Isakesen, E., Ljunngren, E. (2006) New venture financing and subsequent business growth in men- and women-led businesses. Entrepreneurship Theory and Practice, 30(5): 667686.

Audretsch, D., Belitski, M. and Desai, S. (forthcoming, 2018). National business regulations and city entrepreneurship in Europe: A multilevel nested analysis. Entrepreneurship Theory and Practice.

Autio, E., Kenney, M., Mustar, P., Siegel, D. and Wright, M. (2014) Entrepreneurial innovation: the importance of context. Research Policy, 43(7): 1097-1108.

Autor, D. and Salomons, A. (2018) Is automation labor-displacing? Productivity growth, employment, and the labor share, Brookings papers in economy activity, March 8. 
Belitski, M., Chowdhury, F. and Desai, S. (2016) Taxes, corruption, and entry, Small Business Economics, 47(1): 201-216.

Belitski, M. and Desai, S. (2015) What drives ICT clustering in European cities? Journal of Technology Transfer: 1-21.

Bhattacharya, R. (2013) Understanding the spatialities of sexual assault against Indian women in India. Gender, Place, and Culture, 22(9): 1340-1356.

Birch, D. (1987). Job Creation in America: How Our Smallest Companies Put the Most People to Work, Free Press, New York.

Brush, C. (1992). Research on women business owners: Past trends, a new perspective and future directions. Entrepreneurship: Theory and Practice, 16(4), 5-31.

Brush, C., Ali, A., Kelley, D., \& Greene, P. (2017). The influence of human capital factors and context on women's entrepreneurship: Which matters more? Journal of Business Venturing Insights, 8, 105-113.

Carney, M. \& Gedajlovic, E. (2002). The co-evolution of institutional environments and organizational strategies: The rise of family business groups in the ASEAN region. Organization Studies, 23(1), 1-29.

Chirwa, E. (2008). Effects of gender on the performance of micro and small enterprises in Malawi. Development Southern Africa, 25(3), 347-362.

Coad, A. (2018) Firm age: a survey. Journal of Evolutionary Economics, 28(1): 13-43. Coleman, S. (2007). The role of human and financial capital in the profitability and growth of women-owned small firms. Journal of Small Business Management, 45(3), 303-319.

Cuberes, D., Newiak, M. and Teigner, M. (2016) "Gender inequality and macroeconomic performance," pp 31-48 in Kochhar, K., Jain-Chandra, S. and Newiak, M. (eds) Women, work, and economic growth: Leveling the playing field, International Monetary Fund: Washington D.C. Cuberes, D. and Teigner, M. (2016) "Aggregate effects of gender gaps in the labor market: A quantitative estimate," Journal of Human Capital, 10(1): 1-32.

Davis, P., Babakus, E., Englis, P. and Pett, T. (2010). The influence of CEO gender on market orientation and performance in service small and medium-sized service business. Journal of Small Business Management, 48(4), 475-496.

De Bruin, A., Brush, C., and Welter, F. (2007). Advancing a framework for coherent research on women's entrepreneurship. Entrepreneurship Theory and Practice, 26(3), 41-65

Desai, S., Acs, Z. and Weitzel, U. (2014) A model of destructive entrepreneurship, Journal of Conflict Resolution, 57(1): 20-40.

Dezsö, C. and Ross, D. (2012). Does female representation in top management improve firm performance? A panel data investigation. Strategic Management Journal, 33(9): 1072-1089. Djankov, S., La Porta, R., Lopez-de-Silanes, F. and Shleifer, A. (2002). The regulation of entry. The Quarterly Journal of Economics, 117(1): 1-37.

Du Rietz, A., Henrekson, M. (2000). Testing the female underperformance hypothesis. Small Business Economics, 14(1), 1-10.

Dunne, P., and Hughes, A. (1994). Age, size, growth and survival: UK companies in the 1980s. The Journal of Industrial Economics, 115-140.

Economist (2015). Family Companies: To have and to hold. Special Report. April, 18. Enterprise Survey (2014) World Bank.

Estrin, S. and Mickiewicz, T. (2011). Institutions and female entrepreneurship. Small Business Economics, 37(4): 397-415. 
Fairlie, R., and Robb, A. (2009). Gender differences in business performance: Evidence from the characteristics of business owners survey. Small Business Economics, 8(6), 463-478.

Fischer, E., Reuber, A. and Dyke, L. (1993) A theoretical overview and extension of research on sex, gender, and entrepreneurship. Journal of Business Venturing, 8(2): 51-168.

Gaur, A. and Kumar, M. (2018) A systematic approach to conducting review studies: An assessment of content analysis in 25 years of IB research. Journal of World Business, 53(2): 280289.

Gaur A., Kumar, V. and Singh, D. A. (2014). Resources, institutions and internationalization process of emerging economy firms. Journal of World Business, 49: 12-20.

GEM (2017) Global Entrepreneurship Monitor. Available at http://gemconsortium.org/data Goldstein H (2005). Multilevel models. John Wiley \& Sons, Ltd.

Greiner, L. (1972). Evolution and revolution as organizations grow. Harvard Business Review, 37-46.

Haltiwanger, J., Jarmin, R. and Miranda, J. (2013). Who creates jobs? Small versus large versus young. Review of Economics and Statistics, 95(2), 347-361.

Hyytinen, A. and Maliranta, M. (2013). Firm lifecycles and evolution of industry productivity. Research Policy, 42(5): 1080-1098.

Johnson, S. and Storey D.(1993) Male and Female Entrepreneurs and Their Businesses: A

Comparative Study', in S. Allen and C. Truman (eds.), Women Entrepreneurs. London:

Routledge.

Klapper, L., Laeven, L. and Rajan, R. (2006) Entry regulation as a barrier to entrepreneurship, Journal of Financial Economics, 82: 591-629.

Kochan, T., Bezrukova, K., Ely, R., Jackson, S., Joshi, A., Jehn, K and Thomas, D. (2003). The effects of diversity on business performance: Report of the diversity research network. Human resource management, 42(1), 3-21.

Krasniqi, B. and Desai, S. 2016. Institutional drivers of high growth firms: Evidence from 26 transition economies, Small Business Economics, 47(4), 1075-1094.

Krishnan, H., and Park D. (2005). A few good women-on top management teams. Journal of Business Research 58(12): 1712-1720

Lindvert, M., Patel, P. and Wincent, J. (2017) Struggling with social capital: Pakistani women micro entrepreneurs' challenges in acquiring resources. Entrepreneurship and Regional Development, 29(7): 759-790.

McCulloch, C., Searle, SR., \& Neuhaus, JM., (2008). Generalized, Linear, and Mixed Models. 2nd ed. Hoboken, NJ: Wiley.

Marlow, S., and Patton, D. (2005). All credit to men? Entrepreneurship, finance, and gender. Entrepreneurship Theory and Practice, 29(6), 717-735.

Morris, M., Miyasaki, N., Watters, C., Coombes, S. (2006). The dilemma of growth: Understanding venture size choices of women entrepreneur. Journal of Small Business Management, 44(2), 221-244.

McCulloch CE, Searle SR and Neuhaus JM. (2008). Generalized, Linear, and Mixed Models. 2nd ed. Hoboken, NJ: Wiley.

Orser, B., Spence, M., Riding, A., and Carrington, C. (2010). Gender and export propensity. Entrepreneurship Theory and Practice, 34(5), 933-957.

Rabe-Hesketh, S. and Skrondal, A. (2012). Multilevel and Longitudinal Modeling Using Stata. 3rd ed. College Station, TX: Stata Press. 
Robb, A. and Watson, J. (2012). Gender differences in firm performance: Evidence from new ventures in the United States. Journal of Business Venturing, 27(5), 544-558.

Rosa, P., Carter, S. and Hamilton, D. (1996) Gender as a determinant of small business performance: insights from a British study. Small Business Economics, 8(4): 463-478.

Sarri, K. and Trihopoulou, A. (2005). Female entrepreneurs' personal characteristics and motivation: a review of the Greek situation. Women in management review, 20(1), 24-36. Schein, V. (2007). Women in management: Reflections and projections. Women in Management Review, 22(1), 6-18.

Scott, M., and Bruce, R. (1987). Five stages of growth in small business. Long range planning, 20(3), 45-52.

Shrader, C., Blackburn, V. and Iles, P. (1997) Women in management and firm financial performance: an explorative study, Journal of Managerial Issues, 9(3): 355-372.

Smith, N., Smith, V., and Verner, M. (2006). Do women in top management affect firm performance? A panel study of 2,500 Danish firms. International Journal of Productivity and Performance Management, 55(7): 569-593.

Still, L. and Timms, W. (2000). Women's Business: The Flexible Alternative Work Style for Women, Women in Management Review, 15(5/6), 272-282.

Solotaroff, J. and Pande, R. (2014) Violence against women and girls: lessons from South Asia. South Asia Development Forum. World Bank. Washington D.C.

Van Stel A and Storey D. (2004) The Link Between Firm Births and Job Creation: Is There a Upas Tree Effect? Regional Studies 38(8), 893-909.

Van Knippenberg, D., De Dreu, C. and Homan, A. (2004). Work group diversity and group performance: an integrative model and research agenda. Journal of applied psychology, 89(6), 1008.

UN-ESCAP (2015). United Nations-Economic and Social Commission for Asia and the Pacific. "Unlocking the potential of women's entrepreneurship in South Asia," ESCAP-South and West Asia Office Policy Brief No 3, July.

UN-ESCAP (2013) “Overview of the environment for women's entrepreneurship in South Asia and Report on the South Asia Policy Dialogue on women's entrepreneurship," ESCAP-South and South-West Asia Office, November 27.

Wang, S., Guidice, R., Zhou, Y. and Wang, Z. (2017) It's more complicated than we think: The implications of social capital on innovation. Asia Pacific Journal of Management, 34(3): 649674.

Watson, J., and Robinson, S. (2003). Adjusting for risk in comparing the performances of maleand female-controlled SMEs. Journal of Business Venturing, 18, 773-7

Weiler, S., and Bernasek, A. (2001). Dodging the glass ceiling? Networks and the new wave of women entrepreneurs. The Social Science Journal, 38(1), 85-103.

Wooldridge J. (2002) Econometric analysis of cross section and panel data. MIT Press, Cambridge.

World Bank (2019) Women, business and the law (data - 2018). Washington D.C.

World Bank (2016) Women, business and the law: getting to equal. Washington D.C. 
Table 1: Summary statistics and variable description for the full and split samples

\begin{tabular}{|c|c|c|c|c|c|c|c|c|c|c|}
\hline \multirow[b]{2}{*}{ Variable } & \multirow[b]{2}{*}{ Description } & \multicolumn{3}{|c|}{ All firms } & \multicolumn{3}{|c|}{ Women-owned firms } & \multicolumn{3}{|c|}{ Men-owned firms } \\
\hline & & Obs. & Mean & $\begin{array}{l}\text { St. } \\
\text { dev. }\end{array}$ & Obs. & Mean & $\begin{array}{l}\text { St. } \\
\text { dev. }\end{array}$ & Obs. & Mean & $\begin{array}{l}\text { St. } \\
\text { dev. }\end{array}$ \\
\hline Firm growth & $\begin{array}{c}\text { Difference in logs of firm employment in a current } \\
\text { year and three years ago }\end{array}$ & 7,203 & 12.09 & 34.73 & 1,137 & 12.71 & 32.41 & 6,066 & 11.97 & 35.15 \\
\hline Birch index & Birch index (1987) of firm growth & 7,203 & 14.44 & 62.87 & 1,137 & 26.74 & 95.54 & 6,066 & 12.13 & 54.31 \\
\hline Firm productivity & $\begin{array}{c}\text { Difference in logarithms of sales per employee in a } \\
\text { current year and three years ago }\end{array}$ & 6,508 & 0.11 & 0.57 & 1,036 & 0.10 & 0.74 & 5,472 & 0.12 & 0.53 \\
\hline Age category & $\begin{array}{c}\text { Firm age: } 1=\text { start-ups }(0-3 \text { years }) ; 2=\text { survival }(3-7 \\
\text { years, } 3=\text { growth }(7-15 \text { years }), 4=\text { expansion }(15-30 \\
\text { years }), 5=\text { maturity }(>30 \text { years })\end{array}$ & 7,203 & 3.69 & 0.95 & 1,137 & 3.80 & 0.91 & 6,066 & 3.66 & 0.95 \\
\hline Obstacle finance & $\begin{array}{l}\text { Access to finance as obstacle: } 0 \text {-no obstacle; } 1 \text { - } \\
\text { moderate; } 2 \text { - severe }\end{array}$ & 7,203 & 0.16 & 0.36 & 1,137 & 1.00 & 0.00 & 6,066 & 0.00 & 0.00 \\
\hline Female & $\begin{array}{c}\text { Are any of the owners female? 1-yes, zero } \\
\text { otherwise }\end{array}$ & 7,203 & 9.39 & 26.05 & 1,137 & 17.45 & 34.49 & 6,066 & 7.88 & 23.85 \\
\hline Exports & Share of firm's sales direct exports & 7,203 & 0.56 & 0.75 & 1,137 & 0.58 & 0.76 & 6,066 & 0.56 & 0.75 \\
\hline Female in non-production & $\begin{array}{c}\text { Share of female in total FTE who are non- } \\
\text { production worker (human capital) }\end{array}$ & 7,203 & 8.05 & 15.93 & 1,137 & 10.56 & 18.56 & 6,066 & 7.58 & 15.35 \\
\hline Female in production & $\begin{array}{l}\text { Share of female in total FTE who are production } \\
\text { workers (labor) }\end{array}$ & 7,203 & 2.40 & 5.41 & 1,137 & 2.55 & 5.06 & 6,066 & 2.37 & 5.47 \\
\hline Email & Email is used to communicate value chain & 7,203 & 0.78 & 0.42 & 1,137 & 0.90 & 0.30 & 6,066 & 0.76 & 0.43 \\
\hline Web & Web is used to communicate value chain & 7,203 & 0.47 & 0.50 & 1,137 & 0.59 & 0.49 & 6,066 & 0.45 & 0.50 \\
\hline Dealing with regulations & $\begin{array}{c}\text { What \% of senior management time was spent in } \\
\text { dealing with government regulations? }\end{array}$ & 7,203 & 4.85 & 14.50 & 1,137 & 9.17 & 21.07 & 6,066 & 4.04 & 12.75 \\
\hline Technology transfer & $\begin{array}{l}\text { Firm uses foreign technology: 1-yes, zero } \\
\text { otherwise }\end{array}$ & 7,203 & 0.89 & 0.32 & 1,137 & 0.88 & 0.33 & 6,066 & 0.89 & 0.32 \\
\hline GDP & GDP per capita in constant prices & 7,203 & 10.50 & 0.26 & 1,137 & 10.46 & 0.28 & 6,066 & 10.51 & 0.26 \\
\hline Formal registration & $\begin{array}{l}\text { Firm formally registered when it began operations: } \\
\qquad 1 \text {-yes, zero otherwise }\end{array}$ & 7,203 & 0.06 & 0.25 & 1,137 & 0.03 & 0.18 & 6,066 & 0.07 & 0.26 \\
\hline
\end{tabular}

Note: Number of firms is 7,203

Source: Enterprise Surveys World Bank Group (2014) during the 2007-2014 period for India, Pakistan and Bangladesh 
Table 2: Correlation matrix

\begin{tabular}{|c|c|c|c|c|c|c|c|c|c|c|c|c|c|c|}
\hline Variable & 1 & 2 & 3 & 4 & 5 & 6 & 7 & 8 & 9 & 10 & 11 & 12 & 13 & 14 \\
\hline 1. Firm growth & 1 & & & & & & & & & & & & & \\
\hline 2. Birch index & $0.54 *$ & 1 & & & & & & & & & & & & \\
\hline 3. Firm productivity & $-0.24 *$ & $-0.11^{*}$ & 1 & & & & & & & & & & & \\
\hline 4. Age category & $-0.07 *$ & $-0.02 *$ & $-0.02 *$ & 1 & & & & & & & & & & \\
\hline 5. Obstacle finance & 0.01 & $0.08 *$ & -0.01 & $0.05^{*}$ & 1 & & & & & & & & & \\
\hline 6. Female & $0.03 *$ & $0.18^{*}$ & 0.01 & $0.03 *$ & $0.13 *$ & 1 & & & & & & & & \\
\hline 7. Exports & $0.04 *$ & -0.01 & -0.01 & $-0.03 *$ & 0.01 & -0.01 & 1 & & & & & & & \\
\hline 8. Female in non-production & 0.02 & $0.14^{*}$ & 0.01 & $-0.02 *$ & $0.06^{*}$ & $0.28 *$ & $0.05^{*}$ & 1 & & & & & & \\
\hline 9. Female in production & $0.02 *$ & $0.04 *$ & -0.01 & $0.02 *$ & 0.01 & $0.10^{*}$ & $-0.04 *$ & $0.25^{*}$ & 1 & & & & & \\
\hline 10. Email & -0.01 & $0.07 *$ & -0.01 & 0.01 & $0.12^{*}$ & $0.15^{*}$ & $-0.13^{*}$ & 0.01 & $0.10^{*}$ & 1 & & & & \\
\hline 11. Web & 0.02 & $0.13^{*}$ & 0.01 & $0.03 *$ & $0.10^{*}$ & $0.24 *$ & $-0.09 *$ & $0.07 *$ & $0.13^{*}$ & $0.46^{*}$ & 1 & & & \\
\hline 12. Dealing with regulations & 0.02 & $0.04 *$ & 0.01 & $0.06^{*}$ & $0.12 *$ & $0.09 *$ & $-0.02 *$ & $-0.02 *$ & -0.01 & $0.03^{*}$ & $0.05^{*}$ & 1 & & \\
\hline 13. Technology transfer & $-0.07 *$ & $-0.09 *$ & $0.04 *$ & 0.01 & -0.01 & $-0.15^{*}$ & $0.08^{*}$ & $-0.11 *$ & $-0.12 *$ & $-0.12 *$ & $-0.24 *$ & -0.01 & 1 & \\
\hline 14. GDP & -0.01 & $-0.09 *$ & -0.01 & $0.03 *$ & $-0.06^{*}$ & $-0.13 *$ & $-0.12 *$ & $-0.21 *$ & $-0.03 *$ & $0.17 *$ & $0.06^{*}$ & 0.01 & $0.03 *$ & 1 \\
\hline 15. Formal registration & -0.01 & $-0.02 *$ & 0.02 & -0.01 & $-0.05^{*}$ & $-0.02 *$ & 0.02 & $-0.03^{*}$ & $-0.03^{*}$ & $-0.13^{*}$ & $-0.07 *$ & -0.02 & $0.04 *$ & -0.02 \\
\hline
\end{tabular}

Note: * represents significance at the $5 \%$ level. The number of firms is 7,203.

Source: World Bank Enterprise Surveys (2014) during the 2007-2014 period for Bangladesh, India, and Pakistan. 
Table 3: Mixed effects multivariate regression (DV - difference in logs of firm employment in a current year and three years ago)

\begin{tabular}{|c|c|c|c|c|c|c|c|c|c|c|c|}
\hline \multirow[t]{2}{*}{ Sample } & $\begin{array}{l}\text { baseline } \\
\text { all firms }\end{array}$ & all firms & all firms & India & India & $\begin{array}{c}\text { India } \\
\text { Global }\end{array}$ & $\begin{array}{c}\text { India } \\
\text { Global }\end{array}$ & Pakistan & Pakistan & Bangladesh & Bangladesh \\
\hline & $(1)$ & $(2)$ & (3) & (4) & $(5)$ & $(6)$ & $(7)$ & $(8)$ & $(9)$ & $(10)$ & $(11)$ \\
\hline Age group 2 (3-6 years) & & $\begin{array}{c}0.30 \\
(4.20) \\
\end{array}$ & $\begin{array}{c}3.91 \\
(4.46) \\
\end{array}$ & $\begin{array}{c}-3.48 \\
(3.63) \\
\end{array}$ & $\begin{array}{c}1.23 \\
(3.89) \\
\end{array}$ & $\begin{array}{c}-12.32 \\
(10.94) \\
\end{array}$ & $\begin{array}{c}24.04 * * \\
(12.02)\end{array}$ & $\begin{array}{c}9.13 \\
(17.57) \\
\end{array}$ & $\begin{array}{c}-12.17 \\
(18.88)\end{array}$ & $\begin{array}{l}24.86 * \\
(13.38)\end{array}$ & $\begin{array}{c}20.10 \\
(13.42) \\
\end{array}$ \\
\hline Age group 3 ( $7-14$ years) & & $\begin{array}{l}-4.47 \\
(4.07) \\
\end{array}$ & $\begin{array}{r}-0.50 \\
(4.33) \\
\end{array}$ & $\begin{array}{c}-8.04 * * \\
(3.51) \\
\end{array}$ & $\begin{array}{l}-3.95 \\
(3.77) \\
\end{array}$ & $\begin{array}{c}-23.59 * * \\
(9.99) \\
\end{array}$ & $\begin{array}{c}6.96 \\
(11.00) \\
\end{array}$ & $\begin{array}{c}15.53 * * \\
(7.68)\end{array}$ & $\begin{array}{c}11.57 * \\
(6.75)\end{array}$ & $\begin{array}{c}18.48 \\
(13.09) \\
\end{array}$ & $\begin{array}{c}17.53 \\
(13.08) \\
\end{array}$ \\
\hline Age group 4 (15-29 years) & & $\begin{array}{c}-7.93^{*} \\
(4.06)\end{array}$ & $\begin{array}{l}-3.81 \\
(4.32) \\
\end{array}$ & $\begin{array}{c}-10.80^{* * *} * \\
(3.51) \\
\end{array}$ & $\begin{array}{l}-6.84^{*} \\
(3.77)\end{array}$ & $\begin{array}{c}-25.46^{* *} \\
(9.90)\end{array}$ & $\begin{array}{c}5.35 \\
(10.91)\end{array}$ & $\begin{array}{c}3.49 \\
(6.44)\end{array}$ & $\begin{array}{l}12.47 \\
(6.52) \\
\end{array}$ & $\begin{array}{c}13.88 \\
(13.06) \\
\end{array}$ & $\begin{array}{c}14.14 \\
(13.03) \\
\end{array}$ \\
\hline Age group 5 (>30 years) & & $\begin{array}{c}-9.65 * * \\
(4.11)\end{array}$ & $\begin{array}{l}-4.68 \\
(4.38) \\
\end{array}$ & $\begin{array}{c}-12.89 * * * \\
(3.56) \\
\end{array}$ & $\begin{array}{c}-7.98 * * \\
(3.82)\end{array}$ & $\begin{array}{c}-27.0 * * * \\
(9.93) \\
\end{array}$ & $\begin{array}{c}4.13 \\
(10.94)\end{array}$ & $\begin{array}{c}7.49 \\
(5.14) \\
\end{array}$ & $\begin{array}{c}19.02 \\
(12.02)\end{array}$ & $\begin{array}{c}13.59 \\
(13.26) \\
\end{array}$ & $\begin{array}{c}14.26 \\
(13.28)\end{array}$ \\
\hline Female (H1) & & $\begin{array}{c}1.02 \\
(1.14)\end{array}$ & $\begin{array}{c}37.89 * * * \\
(12.58)\end{array}$ & $\begin{array}{c}0.23 \\
(1.04)\end{array}$ & $\begin{array}{c}33.47 * * * \\
(10.23)\end{array}$ & $\begin{array}{c}0.93 \\
(3.49)\end{array}$ & $\begin{array}{c}139.2 * * * \\
(23.31)\end{array}$ & $\begin{array}{c}-11.14 \\
(10.14)\end{array}$ & $\begin{array}{c}89.23 * * \\
(42.06)\end{array}$ & $\begin{array}{l}6.02 * \\
(3.16)\end{array}$ & $\begin{array}{l}1.58 * \\
(0.70)\end{array}$ \\
\hline Exports & & $\begin{array}{l}0.03 * \\
(0.02) \\
\end{array}$ & $\begin{array}{l}0.03 * \\
(0.02)\end{array}$ & $\begin{array}{c}0.05 * * * \\
(0.02)\end{array}$ & $\begin{array}{c}0.05 * * * \\
(0.02)\end{array}$ & $\begin{array}{c}0.05 \\
(0.06)\end{array}$ & $\begin{array}{c}0.04 \\
(0.06) \\
\end{array}$ & $\begin{array}{c}0.05 \\
(0.11) \\
\end{array}$ & $\begin{array}{c}0.07 \\
(0.11) \\
\end{array}$ & $\begin{array}{c}-0.02 \\
(0.04) \\
\end{array}$ & $\begin{array}{l}-0.02 \\
(0.04) \\
\end{array}$ \\
\hline Obstacle finance & & $\begin{array}{c}1.36 * * \\
(0.57)\end{array}$ & $\begin{array}{c}1.72 * * * \\
(0.64)\end{array}$ & $\begin{array}{c}1.31 * * \\
(0.54)\end{array}$ & $\begin{array}{c}1.89 * * * \\
(0.61)\end{array}$ & $\begin{array}{c}5.71 * * * \\
(1.65) \\
\end{array}$ & $\begin{array}{c}5.04 * * * \\
(1.83)\end{array}$ & $\begin{array}{c}1.32 \\
(3.69) \\
\end{array}$ & $\begin{array}{l}2.33 \\
(4.06) \\
\end{array}$ & $\begin{array}{c}0.97 \\
(1.60) \\
\end{array}$ & $\begin{array}{c}0.56 \\
(1.78) \\
\end{array}$ \\
\hline Female in non-production & & $\begin{array}{c}0.02 \\
(0.03) \\
\end{array}$ & $\begin{array}{c}0.02 \\
(0.03) \\
\end{array}$ & $\begin{array}{c}0.03 \\
(0.03) \\
\end{array}$ & $\begin{array}{c}0.03 \\
(0.03) \\
\end{array}$ & $\begin{array}{c}0.04 \\
(0.12) \\
\end{array}$ & $\begin{array}{c}0.05 \\
(0.12) \\
\end{array}$ & $\begin{array}{l}-0.59 \\
(0.54) \\
\end{array}$ & $\begin{array}{c}-0.50 \\
(0.54) \\
\end{array}$ & $\begin{array}{c}0.09 \\
(0.07) \\
\end{array}$ & $\begin{array}{c}0.09 \\
(0.07) \\
\end{array}$ \\
\hline Female in production & & $\begin{array}{c}0.04 \\
(0.08) \\
\end{array}$ & $\begin{array}{c}0.04 \\
(0.08) \\
\end{array}$ & $\begin{array}{c}0.14^{*} \\
(0.07)\end{array}$ & $\begin{array}{l}0.13 * \\
(0.07)\end{array}$ & $\begin{array}{l}0.32 * \\
(0.18) \\
\end{array}$ & $\begin{array}{c}0.24 \\
(0.18) \\
\end{array}$ & $\begin{array}{c}0.42 \\
(1.16) \\
\end{array}$ & $\begin{array}{c}0.41 \\
(1.17) \\
\end{array}$ & $\begin{array}{c}-0.14 \\
(0.23) \\
\end{array}$ & $\begin{array}{l}-0.17 \\
(0.23) \\
\end{array}$ \\
\hline Email & & $\begin{array}{c}1.60 \\
(1.22) \\
\end{array}$ & $\begin{array}{c}1.51 \\
(1.22) \\
\end{array}$ & $\begin{array}{c}3.42 * * * \\
(1.24)\end{array}$ & $\begin{array}{c}3.36 * * * \\
(1.23) \\
\end{array}$ & $\begin{array}{l}6.64 * \\
(3.73) \\
\end{array}$ & $\begin{array}{c}5.57 \\
(3.65) \\
\end{array}$ & $\begin{array}{l}-4.57 \\
(7.43) \\
\end{array}$ & $\begin{array}{l}-4.23 \\
(7.40) \\
\end{array}$ & $\begin{array}{c}0.11 \\
(3.62) \\
\end{array}$ & $\begin{array}{c}0.21 \\
(3.61) \\
\end{array}$ \\
\hline Web & & $\begin{array}{c}0.80 \\
(0.98) \\
\end{array}$ & $\begin{array}{c}0.91 \\
(0.98) \\
\end{array}$ & $\begin{array}{l}-0.03 \\
(0.86) \\
\end{array}$ & $\begin{array}{c}0.04 \\
(0.86) \\
\end{array}$ & $\begin{array}{c}-6.30 * * \\
(2.45) \\
\end{array}$ & $\begin{array}{c}-5.27 * * \\
(2.41) \\
\end{array}$ & $\begin{array}{c}6.95 \\
(7.73) \\
\end{array}$ & $\begin{array}{c}6.59 \\
(7.73) \\
\end{array}$ & $\begin{array}{c}1.82 \\
(3.65) \\
\end{array}$ & $\begin{array}{c}1.76 \\
(3.64) \\
\end{array}$ \\
\hline Dealing with regulations & & $\begin{array}{c}0.03 \\
(0.03) \\
\end{array}$ & $\begin{array}{c}0.03 \\
(0.03) \\
\end{array}$ & $\begin{array}{c}0.01 \\
(0.03) \\
\end{array}$ & $\begin{array}{c}0.01 \\
(0.03)\end{array}$ & $\begin{array}{l}0.12 * \\
(0.07) \\
\end{array}$ & $\begin{array}{l}0.12 * \\
(0.07)\end{array}$ & $\begin{array}{l}-0.04 \\
(0.22) \\
\end{array}$ & $\begin{array}{l}-0.08 \\
(0.22) \\
\end{array}$ & $\begin{array}{c}0.17 \\
(0.12)\end{array}$ & $\begin{array}{c}0.18 \\
(0.12) \\
\end{array}$ \\
\hline Technology transfer & & $\begin{array}{c}-3.72 * * * \\
(1.39) \\
\end{array}$ & $\begin{array}{c}-3.72 * * * \\
(1.39) \\
\end{array}$ & $\begin{array}{c}-0.93 \\
(1.38) \\
\end{array}$ & $\begin{array}{c}-0.94 \\
(1.38) \\
\end{array}$ & $\begin{array}{c}-10.93^{* *} \\
(3.38) \\
\end{array}$ & $\begin{array}{c}-11.15^{* *} \\
(3.30) \\
\end{array}$ & $\begin{array}{c}-15.02 * * \\
(7.54) \\
\end{array}$ & $\begin{array}{c}-15.88 * * \\
(7.52) \\
\end{array}$ & $\begin{array}{l}-4.10 \\
(3.62) \\
\end{array}$ & $\begin{array}{l}-3.93 \\
(3.61) \\
\end{array}$ \\
\hline GDP & & $\begin{array}{c}4.10 \\
(3.74) \\
\end{array}$ & $\begin{array}{c}4.48 \\
(3.74) \\
\end{array}$ & $\begin{array}{l}-0.65 \\
(3.61) \\
\end{array}$ & $\begin{array}{c}-0.14 \\
(3.61) \\
\end{array}$ & $\begin{array}{c}-12.16 \\
(9.71) \\
\end{array}$ & $\begin{array}{r}-13.93 \\
(9.49) \\
\end{array}$ & $\begin{array}{c}-578.0 \\
(456.5) \\
\end{array}$ & $\begin{array}{r}-586.10 \\
(453.8) \\
\end{array}$ & $\begin{array}{c}85.94 \\
(750.6) \\
\end{array}$ & $\begin{array}{c}48.20 \\
(748.2) \\
\end{array}$ \\
\hline Formal registration & & $\begin{array}{c}-5.11 * * * \\
(1.68) \\
\end{array}$ & $\begin{array}{c}-5.03 * * * \\
(1.68) \\
\end{array}$ & $\begin{array}{c}-4.89 * * * \\
(1.78) \\
\end{array}$ & $\begin{array}{c}-4.79 * * * \\
(1.78) \\
\end{array}$ & $\begin{array}{l}-4.34 \\
(3.62) \\
\end{array}$ & $\begin{array}{c}-4.18 \\
(3.54) \\
\end{array}$ & $\begin{array}{c}-11.84 \\
(7.49) \\
\end{array}$ & $\begin{array}{c}-12.89 * \\
(7.50) \\
\end{array}$ & $\begin{array}{l}-2.65 \\
(4.03) \\
\end{array}$ & $\begin{array}{l}-2.74 \\
(4.02) \\
\end{array}$ \\
\hline Female x Age group 2 & & & $\begin{array}{c}-32.56^{* * *} \\
(13.11)\end{array}$ & & $\begin{array}{c}-37.36 * * * \\
(10.75)\end{array}$ & & $\begin{array}{c}-170.60 * * \\
(26.12)\end{array}$ & & $\begin{array}{c}-101.70 * \\
(55.40)\end{array}$ & & $\begin{array}{c}37.96 * * * \\
(13.50)\end{array}$ \\
\hline
\end{tabular}




\begin{tabular}{|c|c|c|c|c|c|c|c|c|c|c|c|}
\hline Female x Age group 3 & & & $\begin{array}{c}-35.45^{* *} \\
(12.71)\end{array}$ & & $\begin{array}{c}-31.98 * * * \\
(10.35)\end{array}$ & & $\begin{array}{c}-131.5^{* *} \\
(24.24)\end{array}$ & & $\begin{array}{r}-76.87 * \\
(46.40)\end{array}$ & & $\begin{array}{c}7.56 \\
(8.67)\end{array}$ \\
\hline Female x Age group 4 & & & $\begin{array}{c}-36.40 * * \\
(12.66)\end{array}$ & & $\begin{array}{c}-31.30 * * * \\
(10.31)\end{array}$ & & $\begin{array}{c}-138.9 * * \\
(23.86)\end{array}$ & & $\begin{array}{c}-99.38 * * \\
(43.38) \\
\end{array}$ & & $\begin{array}{c}3.45 \\
(7.80)\end{array}$ \\
\hline Female x Age group 5 & & & $\begin{array}{c}-41.05^{* *} \\
(12.73)\end{array}$ & & $\begin{array}{c}-36.52 * * \\
(10.38)\end{array}$ & & $\begin{array}{c}-143.7 * * \\
(23.70)\end{array}$ & & & & \\
\hline $\begin{array}{l}\text { Female x Obstacle finance: } \\
\text { moderate }\end{array}$ & & & $\begin{array}{c}1.69 \\
(2.60)\end{array}$ & & $\begin{array}{c}2.58 \\
(2.53)\end{array}$ & & $\begin{array}{l}-3.97 \\
(9.61)\end{array}$ & & $\begin{array}{l}-16.01 \\
(24.03)\end{array}$ & & $\begin{array}{c}2.63 \\
(6.48)\end{array}$ \\
\hline Female x Obstacle finance: severe & & & $\begin{array}{l}-3.48 \\
(3.02)\end{array}$ & & $\begin{array}{l}-4.84 * \\
(2.87)\end{array}$ & & $\begin{array}{c}2.89 \\
(9.23)\end{array}$ & & $\begin{array}{l}-33.26 \\
(24.31)\end{array}$ & & $\begin{array}{c}3.78 \\
(7.82)\end{array}$ \\
\hline Random effect variance constant & $\begin{array}{c}3.45^{* * * *} \\
(0.01)\end{array}$ & $\begin{array}{c}3.99 * * * \\
(0.01)\end{array}$ & $\begin{array}{c}3.50^{* * * *} \\
(0.01)\end{array}$ & $\begin{array}{c}3.28 * * * \\
(0.01)\end{array}$ & $\begin{array}{c}3.28^{* * *} \\
(0.01)\end{array}$ & $\begin{array}{c}3.35^{* * * *} \\
(0.02)\end{array}$ & $\begin{array}{c}3.33^{* * * *} \\
(0.02)\end{array}$ & $\begin{array}{c}4.14 * * * \\
(0.03)\end{array}$ & $\begin{array}{c}4.13^{* * * *} \\
(0.03)\end{array}$ & $\begin{array}{c}3.64^{* * *} \\
(0.02)\end{array}$ & $\begin{array}{c}3.63 * * * \\
(0.02)\end{array}$ \\
\hline $\mathrm{N}$ obs. & 7203 & 7203 & 7203 & 5547 & 5547 & 910 & 910 & 590 & 590 & 1066 & 1066 \\
\hline Chi2 (overall model) & 113.66 & 113.66 & 130.29 & 120.20 & 142.44 & 86.28 & 136.40 & 26.00 & 33.81 & 32.87 & 42.98 \\
\hline Log-likelihood & -64739 & -35505 & -35496 & -26124 & -26114 & -4348 & -4326 & -3285 & -3282 & -5397 & -5392 \\
\hline LR test mixed vs. linear model & 225.44 & 78.50 & 81.52 & 36.2 & 36.5 & 55.47 & 53.68 & 112.51 & 110.25 & 47.25 & 40.28 \\
\hline ICC & 0.08 & 0.13 & 0.13 & 0.08 & 0.07 & 0.07 & 0.07 & 0.12 & 0.12 & 0.03 & 0.03 \\
\hline
\end{tabular}

Note: Significance is $* 0.1 \%$. $* * 0.05 \%$ and $* * * 0.01 \%$, does not include zero. The $90 \%, 95 \%$ and $99 \%$ confidence intervals do not include zero.

Full sample $=7203$ firms in Bangladesh, India and Pakistan. Industry and year controls suppressed to save space. Reference category for age group=0-3 years (start-up stage). Reference category for Obstacle finance $=0$, which is no constraint at all to access finance.

Source: World Bank Enterprise Surveys (2014) during the 2007-2014 period for Bangladesh, India and Pakistan. 
Table 4: Mixed effects multivariate regression (DV - Birch index (1987) of firm growth)

\begin{tabular}{|c|c|c|c|c|c|c|c|c|c|c|c|}
\hline & $\begin{array}{l}\text { baseline } \\
\text { all firms }\end{array}$ & all firms & all firms & India & India & $\begin{array}{c}\text { India } \\
\text { Global }\end{array}$ & $\begin{array}{c}\text { India } \\
\text { Global }\end{array}$ & Pakistan & Pakistan & Bangladesh & Bangladesh \\
\hline & (1) & (2) & (3) & (4) & $(5)$ & (6) & $(7)$ & $(8)$ & $(9)$ & $(10)$ & $(11)$ \\
\hline Age group 2 (3-6 years) & & $\begin{array}{c}9.20 \\
(7.60)\end{array}$ & $\begin{array}{c}9.50 \\
(8.07)\end{array}$ & $\begin{array}{c}4.17 \\
(6.47) \\
\end{array}$ & $\begin{array}{c}7.86 \\
(6.93) \\
\end{array}$ & $\begin{array}{c}-8.73 \\
(10.50)\end{array}$ & $\begin{array}{c}16.13 \\
(11.61)\end{array}$ & $\begin{array}{c}50.85 * * \\
(20.82)\end{array}$ & $\begin{array}{c}-13.61 \\
(21.54)\end{array}$ & $\begin{array}{c}22.85 \\
(32.98)\end{array}$ & $\begin{array}{c}14.35 \\
(33.08)\end{array}$ \\
\hline Age group 3 (7-14 years) & & $\begin{array}{l}4.648 \\
(7.36) \\
\end{array}$ & $\begin{array}{l}5.959 \\
(7.83) \\
\end{array}$ & $\begin{array}{l}1.224 \\
(6.26) \\
\end{array}$ & $\begin{array}{l}3.819 \\
(6.72) \\
\end{array}$ & $\begin{array}{c}-15.14 \\
(9.58) \\
\end{array}$ & $\begin{array}{c}5.362 \\
(10.62) \\
\end{array}$ & $\begin{array}{r}14.44 \\
(8.98) \\
\end{array}$ & $\begin{array}{l}8.281 \\
(7.62) \\
\end{array}$ & $\begin{array}{c}15.99 \\
(32.24) \\
\end{array}$ & $\begin{array}{c}14.55 \\
(32.22) \\
\end{array}$ \\
\hline Age group 4 (15-29 years) & & $\begin{array}{c}1.27 \\
(7.35)\end{array}$ & $\begin{array}{c}2.78 \\
(7.82) \\
\end{array}$ & $\begin{array}{l}-0.40 \\
(6.25)\end{array}$ & $\begin{array}{c}1.62 \\
(6.71)\end{array}$ & $\begin{array}{c}-14.44 \\
(9.50)\end{array}$ & $\begin{array}{c}6.93 \\
(10.54)\end{array}$ & $\begin{array}{c}0.14 \\
(7.59)\end{array}$ & $\begin{array}{c}8.29 \\
(6.62)\end{array}$ & $\begin{array}{c}3.78 \\
(32.17)\end{array}$ & $\begin{array}{c}6.12 \\
(32.11)\end{array}$ \\
\hline Age group 5 (>30 years) & & $\begin{array}{c}-0.18 \\
(7.43)\end{array}$ & $\begin{array}{c}3.44 \\
(7.91)\end{array}$ & $\begin{array}{l}-2.37 \\
(6.34)\end{array}$ & $\begin{array}{c}1.40 \\
(6.81)\end{array}$ & $\begin{array}{c}-16.24 * \\
(9.53)\end{array}$ & $\begin{array}{c}6.40 \\
(10.56)\end{array}$ & $\begin{array}{c}0.11 \\
(7.59)\end{array}$ & & $\begin{array}{c}3.97 \\
(32.66)\end{array}$ & $\begin{array}{c}6.86 \\
(32.72)\end{array}$ \\
\hline Female (H1) & & $\begin{array}{c}6.79 * * * \\
(2.05)\end{array}$ & $\begin{array}{l}22.44^{*} \\
(13.76)\end{array}$ & $\begin{array}{c}-0.22 \\
(1.85) \\
\end{array}$ & $\begin{array}{c}21.44 \\
(18.25) \\
\end{array}$ & $\begin{array}{c}2.67 \\
(3.35) \\
\end{array}$ & $\begin{array}{c}105.0 * * * \\
(22.51)\end{array}$ & $\begin{array}{c}6.59 \\
(12.00) \\
\end{array}$ & $\begin{array}{c}333.9 * * * \\
(47.99)\end{array}$ & $\begin{array}{c}28.69 * * * \\
(7.78) \\
\end{array}$ & $\begin{array}{c}23.54 * * * \\
(7.96) \\
\end{array}$ \\
\hline Exports & & $\begin{array}{c}0.22 * * * \\
(0.03)\end{array}$ & $\begin{array}{c}0.22 * * * \\
(0.03)\end{array}$ & $\begin{array}{c}0.24 * * * \\
(0.03)\end{array}$ & $\begin{array}{c}0.24 * * * \\
(0.03)\end{array}$ & $\begin{array}{c}0.18 * * * \\
(0.06)\end{array}$ & $\begin{array}{c}0.18 * * * \\
(0.06)\end{array}$ & $\begin{array}{l}0.24^{*} \\
(0.13)\end{array}$ & $\begin{array}{c}0.30 * * \\
(0.12)\end{array}$ & $\begin{array}{c}-0.01 \\
(0.11)\end{array}$ & $\begin{array}{c}-0.01 \\
(0.11)\end{array}$ \\
\hline Obstacle finance & & $\begin{array}{c}-1.74 * \\
(1.02)\end{array}$ & $\begin{array}{l}-1.30 \\
(1.15)\end{array}$ & $\begin{array}{l}-0.87 \\
(0.95)\end{array}$ & $\begin{array}{l}-0.27 \\
(1.08)\end{array}$ & $\begin{array}{l}-1.85 \\
(1.58)\end{array}$ & $\begin{array}{l}-0.92 \\
(1.77)\end{array}$ & $\begin{array}{l}-1.00 \\
(4.34)\end{array}$ & $\begin{array}{c}2.81 \\
(4.60)\end{array}$ & $\begin{array}{l}-4.66 \\
(3.86)\end{array}$ & $\begin{array}{l}-4.16 \\
(4.30)\end{array}$ \\
\hline Female in non-production & & $\begin{array}{c}0.34 * * * \\
(0.05)\end{array}$ & $\begin{array}{c}0.35 * * * \\
(0.05)\end{array}$ & $\begin{array}{c}0.12 * * \\
(0.05) \\
\end{array}$ & $\begin{array}{c}0.12 * * \\
(0.05) \\
\end{array}$ & $\begin{array}{l}-0.13 \\
(0.11) \\
\end{array}$ & $\begin{array}{l}-0.14 \\
(0.11) \\
\end{array}$ & $\begin{array}{c}0.02 \\
(0.63) \\
\end{array}$ & $\begin{array}{c}0.32 \\
(0.61) \\
\end{array}$ & $\begin{array}{c}0.74 * * * \\
(0.18)\end{array}$ & $\begin{array}{c}0.73 * * * \\
(0.18) \\
\end{array}$ \\
\hline Female in production & & $\begin{array}{l}-0.07 \\
(0.14)\end{array}$ & $\begin{array}{l}-0.07 \\
(0.14)\end{array}$ & $\begin{array}{l}-0.04 \\
(0.13)\end{array}$ & $\begin{array}{l}-0.05 \\
(0.13)\end{array}$ & $\begin{array}{l}-0.02 \\
(0.17)\end{array}$ & $\begin{array}{l}-0.06 \\
(0.17)\end{array}$ & $\begin{array}{c}2.07 \\
(1.37)\end{array}$ & $\begin{array}{l}2.34 * \\
(1.33)\end{array}$ & $\begin{array}{c}0.30 \\
(0.55)\end{array}$ & $\begin{array}{c}0.25 \\
(0.55)\end{array}$ \\
\hline Email & & $\begin{array}{c}5.86 * * * \\
(2.17)\end{array}$ & $\begin{array}{c}5.61 * * * \\
(2.17)\end{array}$ & $\begin{array}{c}2.21 \\
(2.18)\end{array}$ & $\begin{array}{c}2.16 \\
(2.19) \\
\end{array}$ & $\begin{array}{c}5.26 \\
(3.58) \\
\end{array}$ & $\begin{array}{c}4.28 \\
(3.53) \\
\end{array}$ & $\begin{array}{l}-2.03 \\
(8.78) \\
\end{array}$ & $\begin{array}{l}-0.42 \\
(8.42)\end{array}$ & $\begin{array}{c}8.67 \\
(8.91) \\
\end{array}$ & $\begin{array}{c}9.42 \\
(8.89) \\
\end{array}$ \\
\hline Web & & $\begin{array}{c}11.79 * * * \\
(1.76)\end{array}$ & $\begin{array}{c}11.88 * * * \\
(1.76)\end{array}$ & $\begin{array}{c}8.44 * * * \\
(1.53)\end{array}$ & $\begin{array}{c}8.44 * * * \\
(1.53)\end{array}$ & $\begin{array}{l}1.260 \\
(2.35)\end{array}$ & $\begin{array}{l}1.955 \\
(2.33)\end{array}$ & $\begin{array}{l}13.02 \\
(9.13)\end{array}$ & $\begin{array}{l}10.08 \\
(8.80)\end{array}$ & $\begin{array}{c}25.09 * * * \\
(9.00)\end{array}$ & $\begin{array}{c}24.86^{* * * *} \\
(8.98)\end{array}$ \\
\hline Dealing with regulations & & $\begin{array}{c}0.15 * * * \\
(0.05)\end{array}$ & $\begin{array}{c}0.15^{* * *} * \\
(0.05) \\
\end{array}$ & $\begin{array}{c}0.02 \\
(0.04) \\
\end{array}$ & $\begin{array}{c}0.02 \\
(0.04) \\
\end{array}$ & $\begin{array}{c}0.01 \\
(0.07) \\
\end{array}$ & $\begin{array}{c}0.01 \\
(0.07) \\
\end{array}$ & $\begin{array}{c}0.27 \\
(0.26) \\
\end{array}$ & $\begin{array}{c}0.21 \\
(0.25) \\
\end{array}$ & $\begin{array}{c}1.22 * * * \\
(0.29)\end{array}$ & $\begin{array}{c}1.22 * * * \\
(0.29) \\
\end{array}$ \\
\hline Technology transfer & & $\begin{array}{c}-5.11 * * \\
(2.49)\end{array}$ & $\begin{array}{c}-4.98 * * \\
(2.49) \\
\end{array}$ & $\begin{array}{l}-4.34^{*} \\
(2.42) \\
\end{array}$ & $\begin{array}{l}-4.34^{*} \\
(2.42) \\
\end{array}$ & $\begin{array}{c}-8.22 * * \\
(3.25) \\
\end{array}$ & $\begin{array}{c}-8.06^{* *} \\
(3.20) \\
\end{array}$ & $\begin{array}{r}-11.99 \\
(8.92) \\
\end{array}$ & $\begin{array}{c}-13.64 \\
(8.58) \\
\end{array}$ & $\begin{array}{c}6.78 \\
(8.85) \\
\end{array}$ & $\begin{array}{c}6.59 \\
(8.84) \\
\end{array}$ \\
\hline GDP & & $\begin{array}{l}-1.92 \\
(5.41)\end{array}$ & $\begin{array}{l}-1.60 \\
(5.42)\end{array}$ & $\begin{array}{c}1.17 \\
(6.43)\end{array}$ & $\begin{array}{c}1.73 \\
(6.43)\end{array}$ & $\begin{array}{l}-6.73 \\
(9.32)\end{array}$ & $\begin{array}{l}-8.36 \\
(9.16)\end{array}$ & $\begin{array}{c}-285.9 \\
(540.33)\end{array}$ & $\begin{array}{c}-288.8 \\
(517.12)\end{array}$ & $\begin{array}{c}294.1 \\
(186.43)\end{array}$ & $\begin{array}{c}298.0 \\
(140.78)\end{array}$ \\
\hline Formal registration & & $\begin{array}{l}5.37 * \\
(3.02) \\
\end{array}$ & $\begin{array}{l}-5.23 * \\
(3.02)\end{array}$ & $\begin{array}{l}-4.77 \\
(3.16) \\
\end{array}$ & $\begin{array}{c}-4.67 \\
(3.16) \\
\end{array}$ & $\begin{array}{l}-3.70 \\
(3.47) \\
\end{array}$ & $\begin{array}{c}-3.24 \\
(3.42) \\
\end{array}$ & $\begin{array}{c}-6.63 \\
(8.82) \\
\end{array}$ & $\begin{array}{c}-7.77 \\
(8.51) \\
\end{array}$ & $\begin{array}{l}-8.21 \\
(9.90) \\
\end{array}$ & $\begin{array}{c}-8.94 \\
(9.87) \\
\end{array}$ \\
\hline Female x Age group 2 & & & $\begin{array}{c}-4.53 \\
(23.73) \\
\end{array}$ & & $\begin{array}{c}-30.03 \\
(19.18) \\
\end{array}$ & & $\begin{array}{c}-119.1 * * \\
(25.21) \\
\end{array}$ & & $\begin{array}{c}-279.1 * * * \\
(52.90)\end{array}$ & & $\begin{array}{c}83.38 * * \\
(33.28) \\
\end{array}$ \\
\hline
\end{tabular}




\begin{tabular}{|c|c|c|c|c|c|c|c|c|c|c|c|}
\hline Female x Age group 3 & & & $\begin{array}{c}-13.61 \\
(22.99) \\
\end{array}$ & & $\begin{array}{c}-21.22 \\
(18.48) \\
\end{array}$ & & $\begin{array}{c}-83.84 * * * \\
(23.40) \\
\end{array}$ & & $\begin{array}{c}-339.5^{* * *} * \\
(49.49) \\
\end{array}$ & & $\begin{array}{c}20.95 \\
(21.38) \\
\end{array}$ \\
\hline Female x Age group 4 & & & $\begin{array}{l}-15.16 \\
(22.90)\end{array}$ & & $\begin{array}{c}-18.03 \\
(18.40)\end{array}$ & & $\begin{array}{c}-100.6^{* * *} * \\
(23.03)\end{array}$ & & $\begin{array}{c}-340.5^{* * *} \\
(49.49)\end{array}$ & & $\begin{array}{c}3.92 \\
(19.23)\end{array}$ \\
\hline Female x Age group 5 & & & $\begin{array}{l}-26.96 \\
(23.04) \\
\end{array}$ & & $\begin{array}{l}-27.69 \\
(18.53) \\
\end{array}$ & & $\begin{array}{c}-110.2 * * * \\
(20.88) \\
\end{array}$ & & & & \\
\hline Female x Obstacle finance moderate & & & $\begin{array}{c}5.24 \\
(4.71)\end{array}$ & & $\begin{array}{c}6.17 \\
(4.51)\end{array}$ & & $\begin{array}{l}-9.70 \\
(9.28)\end{array}$ & & $\begin{array}{l}-20.98 \\
(27.42)\end{array}$ & & $\begin{array}{l}-15.20 \\
(15.94)\end{array}$ \\
\hline Female x Obstacle finance severe & & & $\begin{array}{l}-1.70 \\
(3.47)\end{array}$ & & $\begin{array}{l}-4.95 * \\
(2.91)\end{array}$ & & $\begin{array}{l}-7.91 \\
(6.91)\end{array}$ & & $\begin{array}{c}-70.60 * * \\
(27.74)\end{array}$ & & $\begin{array}{c}-5.06 \\
(19.25)\end{array}$ \\
\hline Random effect variance constant & $\begin{array}{c}4.106^{* * * *} \\
(0.01)\end{array}$ & $\begin{array}{c}4.096^{* * * *} \\
(0.01)\end{array}$ & $\begin{array}{c}4.095^{* * * *} \\
(0.01)\end{array}$ & $\begin{array}{c}3.864 * * * \\
(0.01)\end{array}$ & $\begin{array}{c}3.863^{* * * *} \\
(0.01)\end{array}$ & $\begin{array}{c}3.313 * * * \\
(0.02)\end{array}$ & $\begin{array}{c}3.295^{* * * *} \\
(0.02)\end{array}$ & $\begin{array}{c}4.311 * * * \\
\quad(0.03)\end{array}$ & $\begin{array}{c}4.266^{* * * *} \\
(0.03)\end{array}$ & $\begin{array}{c}4.543^{* * * *} \\
(0.02)\end{array}$ & $\begin{array}{c}4.539 * * * \\
(0.02)\end{array}$ \\
\hline N obs. & 7203 & 7203 & 7203 & 5547 & 5547 & 910 & 910 & 590 & 590 & 1066 & 1066 \\
\hline Chi2 (overall model) & 570.9 & 470.9 & 485.5 & 192.2 & 204.1 & 69.7 & 106.0 & 50.9 & 110.1 & 195.5 & 206.2 \\
\hline Log-likelihood & -73337 & -39754 & -39747 & -29320 & -29314 & -4311 & -4294 & -3382 & -3357 & -6355 & -6351 \\
\hline LR test mixed vs. linear model & 311.21 & 77.85 & 78.36 & 55.20 & 56.12 & 0.25 & 0.24 & 1.51 & 1.51 & 0.05 & 0.05 \\
\hline ICC & 0.04 & 0.03 & 0.03 & 0.02 & 0.02 & 0.07 & 0.07 & 0.02 & 0.02 & 0 & 0 \\
\hline
\end{tabular}

Note: Significance is $* 0.1 \%$. $* * 0.05 \%$ and $* * * 0.01 \%$, does not include zero. The $90 \%, 95 \%$ and $99 \%$ confidence intervals do not include zero.

Full sample $=7203$ firms which includes firms in Bangladesh, India and Pakistan. Industry and year controls suppressed to save space. Reference category for age group $=0-3$ years (start-up stage). Reference category for Obstacle finance $=0$ which is no constraint at all to access finance.

Source: World Bank Enterprise Surveys (2014) during the 2007-2014 period for Bangladesh, India and Pakistan. 


\section{APPENDIX A}

Table A1: Robustness check - mixed effects multivariate regression (DV: difference in logarithms of sales per employee in a current year and three years ago)

\begin{tabular}{|c|c|c|c|c|c|c|c|c|c|c|c|}
\hline & $\begin{array}{l}\text { baseline } \\
\text { all firms }\end{array}$ & all firms & all firms & India & India & $\begin{array}{c}\text { India } \\
\text { Global } \\
\end{array}$ & $\begin{array}{c}\text { India } \\
\text { Global }\end{array}$ & Pakistan & Pakistan & Bangladesh & Bangladesh \\
\hline & (1) & $(2)$ & $(3)$ & (4) & $(5)$ & (6) & (7) & $(8)$ & (9) & $(10)$ & $(11)$ \\
\hline Age group 2 (3-6 years) & & $\begin{array}{l}-0.13 \\
(0.11) \\
\end{array}$ & $\begin{array}{c}-0.20 * \\
(0.12)\end{array}$ & $\begin{array}{c}0.03 \\
(0.08) \\
\end{array}$ & $\begin{array}{c}-0.03 \\
(0.09) \\
\end{array}$ & $\begin{array}{c}0.10 \\
(0.19) \\
\end{array}$ & $\begin{array}{c}-0.52 * * \\
(0.26)\end{array}$ & $\begin{array}{c}0.49 \\
(0.76) \\
\end{array}$ & $\begin{array}{c}0.32 \\
(0.91) \\
\end{array}$ & $\begin{array}{c}-0.59 * * \\
(0.23)\end{array}$ & $\begin{array}{c}-0.55^{*} * \\
(0.23)\end{array}$ \\
\hline Age group 3 (7-14 years) & & $\begin{array}{c}-0.14 \\
(0.11) \\
\end{array}$ & $\begin{array}{c}-0.22 * * \\
(0.11)\end{array}$ & $\begin{array}{c}0.02 \\
(0.08) \\
\end{array}$ & $\begin{array}{l}-0.05 \\
(0.09) \\
\end{array}$ & $\begin{array}{c}0.13 \\
(0.18) \\
\end{array}$ & $\begin{array}{c}-0.42 * \\
(0.25)\end{array}$ & $\begin{array}{c}0.25 \\
(0.24) \\
\end{array}$ & $\begin{array}{l}-0.02 \\
(0.20) \\
\end{array}$ & $\begin{array}{c}-0.59 * * * \\
(0.23)\end{array}$ & $\begin{array}{c}-0.57 * * \\
(0.23)\end{array}$ \\
\hline Age group 4 (15-29 years) & & $\begin{array}{l}-0.15 \\
(0.11) \\
\end{array}$ & $\begin{array}{c}-0.23 * * \\
(0.11)\end{array}$ & $\begin{array}{c}0.01 \\
(0.08) \\
\end{array}$ & $\begin{array}{c}-0.06 \\
(0.09) \\
\end{array}$ & $\begin{array}{c}0.11 \\
(0.18) \\
\end{array}$ & $\begin{array}{l}-0.44^{*} \\
(0.25) \\
\end{array}$ & $\begin{array}{l}0.34^{*} \\
(0.20) \\
\end{array}$ & $\begin{array}{c}0.05 \\
(0.20) \\
\end{array}$ & $\begin{array}{c}-0.61 * * * \\
(0.23)\end{array}$ & $\begin{array}{c}-0.61 * * * \\
(0.23)\end{array}$ \\
\hline Age group 5 (>30 years) & & $\begin{array}{c}-0.183 * \\
(0.11)\end{array}$ & $\begin{array}{c}-0.23 * * \\
(0.11)\end{array}$ & $\begin{array}{c}0.01 \\
(0.08) \\
\end{array}$ & $\begin{array}{l}-0.06 \\
(0.09) \\
\end{array}$ & $\begin{array}{c}0.11 \\
(0.18) \\
\end{array}$ & $\begin{array}{c}-0.45^{*} \\
(0.25) \\
\end{array}$ & $\begin{array}{c}0.31 \\
(0.22) \\
\end{array}$ & $\begin{array}{c}0.09 \\
(0.15) \\
\end{array}$ & $\begin{array}{c}-0.60 * * * \\
(0.23)\end{array}$ & $\begin{array}{c}-0.57 * * \\
(0.23)\end{array}$ \\
\hline Female (H1) & & $\begin{array}{l}-0.03 \\
(0.02)\end{array}$ & $\begin{array}{c}-0.58 * \\
(0.30)\end{array}$ & $\begin{array}{c}0.01 \\
(0.01) \\
\end{array}$ & $\begin{array}{l}-0.38^{*} \\
(0.20)\end{array}$ & $\begin{array}{c}0.01 \\
(0.04)\end{array}$ & $\begin{array}{c}-1.13 * * * \\
(0.36)\end{array}$ & $\begin{array}{c}-1.33 * * * \\
(0.37)\end{array}$ & $\begin{array}{l}-2.85^{*} \\
(1.50) \\
\end{array}$ & $\begin{array}{c}0.01 \\
(0.05)\end{array}$ & $\begin{array}{l}-0.01 \\
(0.13)\end{array}$ \\
\hline Exports & & $\begin{array}{c}0.01 \\
(0.00) \\
\end{array}$ & $\begin{array}{c}0.01 \\
(0.00) \\
\end{array}$ & $\begin{array}{c}0.01 \\
(0.00) \\
\end{array}$ & $\begin{array}{c}0.01 \\
(0.00) \\
\end{array}$ & $\begin{array}{c}0.01 \\
(0.00) \\
\end{array}$ & $\begin{array}{c}0.01 \\
(0.00) \\
\end{array}$ & $\begin{array}{c}0.01 \\
(0.00) \\
\end{array}$ & $\begin{array}{c}0.01 \\
(0.00) \\
\end{array}$ & $\begin{array}{c}0.01 \\
(0.00) \\
\end{array}$ & $\begin{array}{c}0.01 \\
(0.00) \\
\end{array}$ \\
\hline Obstacle finance & & $\begin{array}{c}-0.01 \\
(0.01) \\
\end{array}$ & $\begin{array}{l}-0.01 * \\
(0.01) \\
\end{array}$ & $\begin{array}{c}-0.03 * * * \\
(0.01)\end{array}$ & $\begin{array}{c}-0.03 * * * \\
(0.01)\end{array}$ & $\begin{array}{c}-0.05 * * \\
(0.02)\end{array}$ & $\begin{array}{c}-0.04 * * \\
(0.02)\end{array}$ & $\begin{array}{c}0.26^{* *} \\
(0.12)\end{array}$ & $\begin{array}{c}0.10 \\
(0.13) \\
\end{array}$ & $\begin{array}{l}-0.03 \\
(0.03) \\
\end{array}$ & $\begin{array}{l}-0.02 \\
(0.03) \\
\end{array}$ \\
\hline Female in non-production & & $\begin{array}{c}0.01 \\
(0.00)\end{array}$ & $\begin{array}{c}0.01 \\
(0.00) \\
\end{array}$ & $\begin{array}{c}0.01 \\
(0.00) \\
\end{array}$ & $\begin{array}{c}0.01 \\
(0.00)\end{array}$ & $\begin{array}{c}0.01 \\
(0.00)\end{array}$ & $\begin{array}{c}0.01 \\
(0.00)\end{array}$ & $\begin{array}{c}0.01 \\
(0.02)\end{array}$ & $\begin{array}{c}0.01 \\
(0.02) \\
\end{array}$ & $\begin{array}{c}0.01 \\
(0.00) \\
\end{array}$ & $\begin{array}{c}0.01 \\
(0.00) \\
\end{array}$ \\
\hline Female in production & & $\begin{array}{c}0.01 \\
(0.00) \\
\end{array}$ & $\begin{array}{c}0.01 \\
(0.00) \\
\end{array}$ & $\begin{array}{c}0.01 \\
(0.00) \\
\end{array}$ & $\begin{array}{c}0.01 \\
(0.00) \\
\end{array}$ & $\begin{array}{c}0.01 \\
(0.00) \\
\end{array}$ & $\begin{array}{c}0.01 \\
(0.00) \\
\end{array}$ & $\begin{array}{c}0.01 \\
(0.06) \\
\end{array}$ & $\begin{array}{c}0.01 \\
(0.06) \\
\end{array}$ & $\begin{array}{c}0.01 \\
(0.00) \\
\end{array}$ & $\begin{array}{c}0.01 \\
(0.00) \\
\end{array}$ \\
\hline Email & & $\begin{array}{l}-0.02 \\
(0.02)\end{array}$ & $\begin{array}{l}-0.02 \\
(0.02)\end{array}$ & $\begin{array}{l}-0.02 \\
(0.02)\end{array}$ & $\begin{array}{l}-0.02 \\
(0.02)\end{array}$ & $\begin{array}{l}-0.02 \\
(0.02)\end{array}$ & $\begin{array}{l}-0.02 \\
(0.05)\end{array}$ & $\begin{array}{l}-0.02 \\
(0.05)\end{array}$ & $\begin{array}{c}0.17 \\
(0.24)\end{array}$ & $\begin{array}{c}0.11 \\
(0.24)\end{array}$ & $\begin{array}{c}0.03 \\
(0.06)\end{array}$ \\
\hline Web & & $\begin{array}{c}0.01 \\
(0.02) \\
\end{array}$ & $\begin{array}{c}0.01 \\
(0.02) \\
\end{array}$ & $\begin{array}{c}0.01 \\
(0.02) \\
\end{array}$ & $\begin{array}{c}0.01 \\
(0.01) \\
\end{array}$ & $\begin{array}{c}0.01 \\
(0.01) \\
\end{array}$ & $\begin{array}{c}0.08 * * * \\
(0.03)\end{array}$ & $\begin{array}{c}0.07 * * \\
(0.03)\end{array}$ & $\begin{array}{c}-0.316 \\
(0.26) \\
\end{array}$ & $\begin{array}{l}-0.42^{*} \\
(0.26) \\
\end{array}$ & $\begin{array}{c}0.04 \\
(0.06) \\
\end{array}$ \\
\hline Dealing with regulations & & $\begin{array}{c}0.01 \\
(0.00) \\
\end{array}$ & $\begin{array}{c}0.01 \\
(0.00) \\
\end{array}$ & $\begin{array}{c}0.01 \\
(0.00) \\
\end{array}$ & $\begin{array}{c}0.01 \\
(0.00) \\
\end{array}$ & $\begin{array}{c}0.01 \\
(0.00) \\
\end{array}$ & $\begin{array}{c}0.01 \\
(0.00)\end{array}$ & $\begin{array}{c}0.01 \\
(0.00) \\
\end{array}$ & $\begin{array}{c}0.01 \\
(0.01)\end{array}$ & $\begin{array}{c}0.01 \\
(0.01) \\
\end{array}$ & $\begin{array}{c}0.01 \\
(0.00) \\
\end{array}$ \\
\hline Technology transfer & & $\begin{array}{c}0.07 * * * \\
(0.02)\end{array}$ & $\begin{array}{c}0.08 * * * \\
(0.02)\end{array}$ & $\begin{array}{c}0.08 * * * \\
(0.02)\end{array}$ & $\begin{array}{c}0.04 * * \\
(0.02)\end{array}$ & $\begin{array}{c}0.04 * * \\
(0.02)\end{array}$ & $\begin{array}{c}0.13 * * * \\
(0.04)\end{array}$ & $\begin{array}{c}0.13 * * * \\
(0.04)\end{array}$ & $\begin{array}{c}0.28 \\
(0.25)\end{array}$ & $\begin{array}{c}0.40 \\
(0.25)\end{array}$ & $\begin{array}{l}0.10^{*} \\
(0.06)\end{array}$ \\
\hline GDP & & $\begin{array}{l}-0.04 \\
(0.05)\end{array}$ & $\begin{array}{l}-0.03 \\
(0.05)\end{array}$ & $\begin{array}{l}-0.03 \\
(0.05)\end{array}$ & $\begin{array}{l}-0.03 \\
(0.05)\end{array}$ & $\begin{array}{l}-0.03 \\
(0.05)\end{array}$ & $\begin{array}{l}-0.03 \\
(0.12)\end{array}$ & $\begin{array}{l}-0.03 \\
(0.12)\end{array}$ & $\begin{array}{c}-0.56 \\
(11.35) \\
\end{array}$ & $\begin{array}{c}-2.08 \\
(11.05)\end{array}$ & $\begin{array}{c}8.42 \\
(12.29)\end{array}$ \\
\hline Formal registration & & $\begin{array}{c}0.06 * * \\
(0.03)\end{array}$ & $\begin{array}{c}0.06 * * \\
(0.03) \\
\end{array}$ & $\begin{array}{c}0.08 * * * \\
(0.02)\end{array}$ & $\begin{array}{c}0.08 * * * \\
(0.02) \\
\end{array}$ & $\begin{array}{c}0.02 \\
(0.04) \\
\end{array}$ & $\begin{array}{c}0.02 \\
(0.04) \\
\end{array}$ & $\begin{array}{l}-0.02 \\
(0.22) \\
\end{array}$ & $\begin{array}{l}-0.09 \\
(0.21) \\
\end{array}$ & $\begin{array}{c}0.01 \\
(0.07) \\
\end{array}$ & $\begin{array}{c}0.01 \\
(0.07) \\
\end{array}$ \\
\hline Female x Age group 2 & & & $0.54 *$ & & $0.38 *$ & & $1.50 * * *$ & & 2.01 & & -0.05 \\
\hline
\end{tabular}




\begin{tabular}{|c|c|c|c|c|c|c|c|c|c|c|c|}
\hline & & & $(0.31)$ & & $(0.20)$ & & $(0.39)$ & & $(1.87)$ & & $(0.23)$ \\
\hline Female x Age group 3 & & & $\begin{array}{c}0.62 * * \\
(0.31)\end{array}$ & & $\begin{array}{c}0.41 * * \\
(0.20)\end{array}$ & & $\begin{array}{c}1.11 * * * \\
(0.37)\end{array}$ & & $\begin{array}{c}0.26 \\
(1.50) \\
\end{array}$ & & $\begin{array}{c}0.07 \\
(0.15) \\
\end{array}$ \\
\hline Female x Age group 4 & & & $\begin{array}{l}0.57 * \\
(0.31) \\
\end{array}$ & & $\begin{array}{c}0.37 * \\
(0.20)\end{array}$ & & $\begin{array}{c}1.10 * * * \\
(0.36)\end{array}$ & & $\begin{array}{c}0.24 \\
(1.40) \\
\end{array}$ & & $\begin{array}{c}0.09 \\
(0.13) \\
\end{array}$ \\
\hline Female x Age group 5 & & & $\begin{array}{c}0.45 \\
(0.31) \\
\end{array}$ & & $\begin{array}{c}0.40 * * \\
(0.20) \\
\end{array}$ & & $\begin{array}{c}1.22 * * * \\
(0.36) \\
\end{array}$ & & & & \\
\hline Female x Obstacle finance moderate & & & $\begin{array}{l}-0.04 \\
(0.05)\end{array}$ & & $\begin{array}{l}-0.05 \\
(0.03)\end{array}$ & & $\begin{array}{c}0.03 \\
(0.13)\end{array}$ & & $\begin{array}{c}1.15 \\
(0.86)\end{array}$ & & $\begin{array}{l}-0.09 \\
(0.11)\end{array}$ \\
\hline Female x Obstacle finance severe & & & $\begin{array}{c}0.06 \\
(0.05) \\
\end{array}$ & & $\begin{array}{c}0.01 \\
(0.04) \\
\end{array}$ & & $\begin{array}{l}-0.04 \\
(0.12)\end{array}$ & & $\begin{array}{c}3.36 * * * \\
(0.89)\end{array}$ & & $\begin{array}{l}-0.06 \\
(0.13) \\
\end{array}$ \\
\hline Random effect variance constant & $\begin{array}{c}-2.67 * * * \\
(0.19)\end{array}$ & $\begin{array}{c}-2.72 * * * \\
(0.20)\end{array}$ & $\begin{array}{c}-2.71 * * * \\
(0.19)\end{array}$ & $\begin{array}{c}-2.62 * * * \\
(0.17)\end{array}$ & $\begin{array}{c}-2.62 * * * \\
(0.17)\end{array}$ & $\begin{array}{c}-3.09 * * * \\
(0.54)\end{array}$ & $\begin{array}{c}-3.20 * * * \\
(0.57)\end{array}$ & $\begin{array}{c}-16.90 \\
(10.31)\end{array}$ & $\begin{array}{c}-20.18 * * \\
(10.07)\end{array}$ & $\begin{array}{c}-2.43 * * * \\
(0.52)\end{array}$ & $\begin{array}{c}-2.38 * * * \\
(0.51)\end{array}$ \\
\hline N obs. & 6508 & 6508 & 6508 & 5127 & 5127 & 816 & 816 & 375 & 375 & 1006 & 1006 \\
\hline Chi2 (overall model) & 145.4 & 42.4 & 63.9 & 53.8 & 62.5 & 46.6 & 64.9 & 48.4 & 72.8 & 28.1 & 30.9 \\
\hline Log-likelihood & -10614 & -5596 & -5500 & -1920 & -1916 & -293 & -284 & -698 & -688 & -955 & -954 \\
\hline LR test mixed vs. linear model & 54.75 & 35.85 & 34.30 & 130.24 & 129.12 & 3.81 & 5.20 & 1.12 & 1.10 & 4.10 & 4.65 \\
\hline ICC & 0.03 & 0.02 & 0.02 & 0.04 & 0.04 & 0.02 & 0.02 & 0.00 & 0.00 & 0.02 & 0.02 \\
\hline
\end{tabular}

Note: Significance is $* 0.1 \%$. $* * 0.05 \%$ and $* * * 0.01 \%$, does not include zero. The $90 \%, 95 \%$ and $99 \%$ confidence intervals do not include zero.

Sample $=6,508$ firms which includes firms in Bangladesh, India, and Pakistan. Industry and year controls suppressed to save space. Reference category for Age group $=0-3$ years (start-up stage). Reference category for Obstacle finance $=0$ which is no constraint at all to access finance.

Source: World Bank Enterprise Surveys (2014) during the 2007-2014 period on Bangladesh, India, and Pakistan. 
Figure A1: Women-owned firms in five stage of growth - Bangladesh, India, and Pakistan (2007-2014)

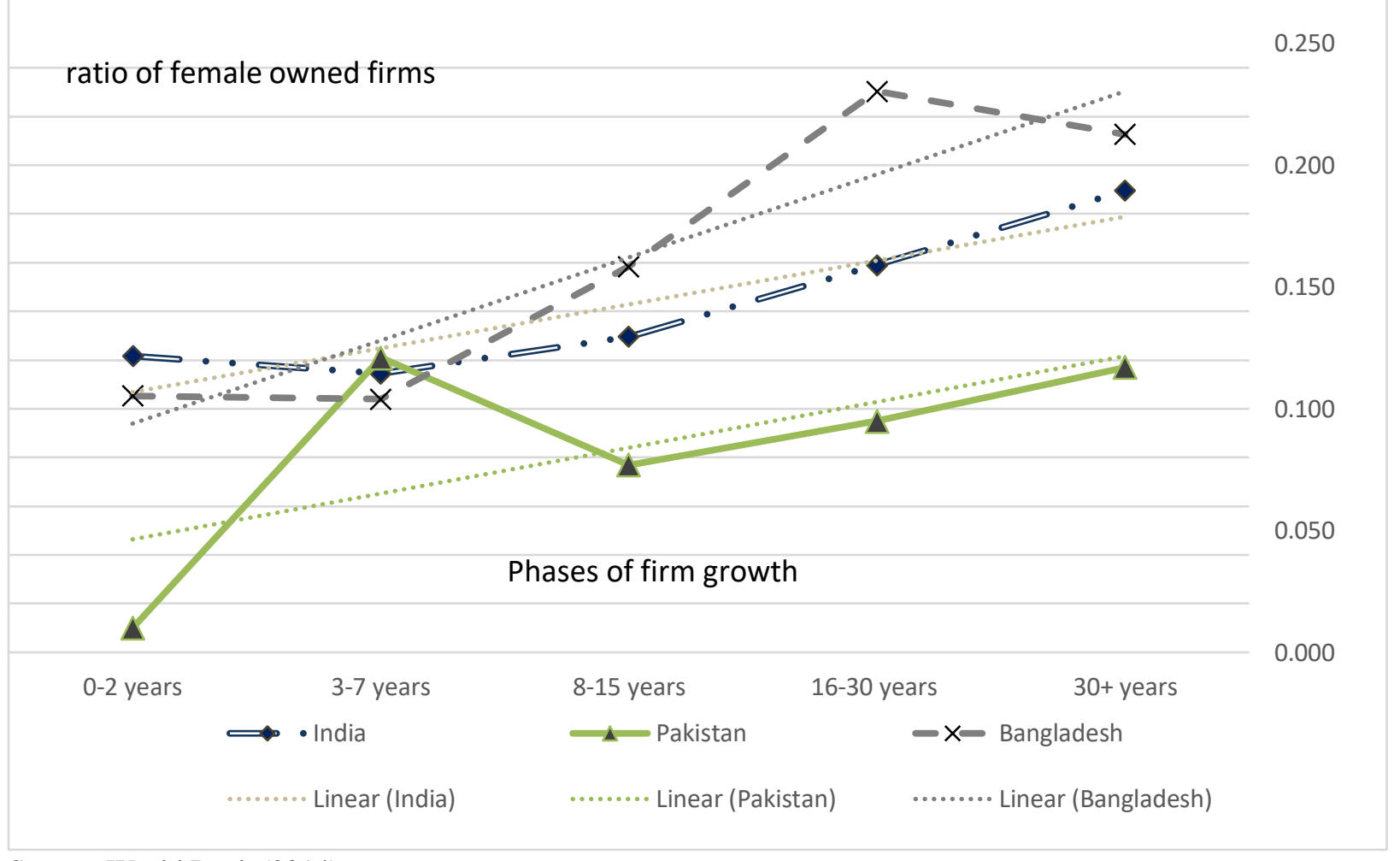

Source: World Bank (2014) 